OPEN ACCESS

Edited by:

Karl Tsim,

Hong Kong University of Science and

Technology, China

Reviewed by:

José Antonio González,

University of Salamanca, Spain

${ }^{*}$ Correspondence:

Sakina Mussarat

sakinamussarat78@yahoo.com

Rehman All

rehmanali7680@gmail.com

Muhammad Adnan

ghurzang@hotmail.com

${ }^{t}$ These authors have contributed equally to this work and share first authorship

Specialty section: This article was submitted to

Ethnopharmacology,

a section of the journal

Frontiers in Pharmacology

Received: 03 January 2021

Accepted: 29 June 2021

Published: 20 August 2021

Citation:

Mussarat S, Ali R, Ali S, Mothana RA, Ullah R and Adnan M (2021) Medicinal Animals and Plants as Alternative and Complementary Medicine in Southern Regions of Khyber

Pakhtunkhwa, Pakistan.

Front. Pharmacol. 12:649046. doi: 10.3389/fphar.2021.649046

\section{Medicinal Animals and Plants as Alternative and Complementary Medicine in Southern Regions of Khyber Pakhtunkhwa, Pakistan}

\author{
Sakina Mussarat ${ }^{1+*}$, Rehman $A l i^{2 \dagger *}$, Shandana $A i^{2}$, Ramzi A. Mothana ${ }^{3}$, Riaz Ullah ${ }^{3}$ and \\ Muhammad Adnan ${ }^{1 *}$
}

${ }^{1}$ Department of Botanical and Environmental Sciences, Faculty of Biological Sciences, Kohat University of Science and Technology, Kohat, Pakistan, ${ }^{2}$ Department of Zoology, Faculty of Biological Sciences, Kohat University of Science and Technology, Kohat, Pakistan, ${ }^{3}$ Department of Pharmacognosy, College of Pharmacy, King Saud University, Riyadh, Saudi Arabia

Background: Local communities use animals and plants as common traditional therapies for various diseases. The study aimed to document animals and animal-plant mixture recipes that are used as alternative and complementary medicine in southern regions of Khyber Pakhtunkhwa, Pakistan.

Methods: The data were collected (2017-2018) in three remote areas (Dera Ismail Khan, Bannu, and Lakki Marwat) through questionnaires and face-to-face interviews with local inhabitants. Data on ethnomedicinal uses and cultural values of animal products or parts and their mixture with plants were analyzed using various indices such as frequency of citation (FC), informant consensus (FIC), and fidelity level (FL) to find the highly preferred species in the area.

Results: A total of 185 informants (117 females and 68 males) were interviewed. The study documented 32 animal species, vertebrates $(n=24)$ and invertebrates $(n=8)$, for curing 37 types of diseases. Mammals $(n=13)$ were among the most commonly utilized species followed by birds $(n=8)$, arthropods $(n=7)$, reptiles $(n=2)$, and fishes and annelids $(n=1$ each). Among the reported animals, Herpestes edwardsi (mongoose), Macaca mulatta (monkey), Labeo rohita (rohu), Oryctolagus cuniculus (rabbit), and Streptopelia decaocto (dove) were the newly reported species used as alternative medicine. The meat of Capra hircus (goat), monkey, and rabbit was used to treat chronic diseases such as hepatitis C, cancer, epilepsy, and asthma. A total of 17 plants belonging to 15 botanical families were used in combination with animal parts/products. The commonly used families were Piperaceae (31\%) followed by Apiaceae (27\%). The notable plant species in combination with animal products were Curcuma longa, Piper nigrum, Coriandrum sativum, Brassica rapa, and Phoenix dactylifera. Seeds were the highest used part in animal-plant mixture recipes. Gallus gallus (chicken) and Columba livia (pigeon) secured the highest $(F C=28)$ and $(F L=80 \%)$, respectively. $F I C$ results had shown the highest degree of consensus for general body weakness $(F I C=0.88)$ and pyrexia $(F I C=0.86)$. 
Conclusion: Our findings suggest that local communities in the southern regions of Khyber Pakhtunkhwa have substantial knowledge about the formulation of ethnomedicines from both flora and fauna that need urgent documentation to avoid eroding and for conservational purposes. The newly reported phytozootherapeutic recipes and animal species can potentially be a source of pharmacologically active constituents and should be checked experimentally for further confirmation.

Keywords: zootherapy, ethnobiology, livestock, Khyber Pakhtunkhwa, quantitative indices

\section{INTRODUCTION}

Since ancient times human beings are aware of ethnobiological uses and depend on fauna and flora for their medicines, food, clothing, and other resources of living (Lohani et al., 2008). About 170 member states $(88 \%)$ of the World Health Organization (WHO) claimed to use complementary and alternative medicines in 2018 (WHO, 2019). Approximately, 65\% of the world population relies on alternative medicines derived from natural resources for their primary health care Cragg and Newman (2013) as these are comprised of different bioactive compounds which may be more effective with the least toxicity as compared to synthetic drugs (Oudhia, 1995; Alves and Rosa, 2005). Traditional Chinese medicines, comprising more than 1,500 animal species, Unani medicine consists of about 500 species of invertebrates, while Ayurvedic system of medicine also depends on animal species and their products along with medicinal flora that denotes the importance of fauna and flora in healing ailments (Oudhia, 1995; Tripathy, 1995; Alves and Rosa, 2005).

Pakistan hosts remarkable biodiversity of both fauna and flora Ali (1998), Khan (2004), Mirza and Wasiq, (2007) where most medicines are of plant origin. Tibb-e Islami Dawa Khana (herbal drug markets) reported 600 plant species, general practitioners and tabibs (GPs of Unani medicine) used about 50,000 species of plants, and many unlicensed health practitioners spread in remote hilly and rural areas of Pakistan are using more than 200 plant species in crude drug preparation (Umair et al., 2019). Rural people, who have century's old traditional knowledge transferred from their ancestors and propagated from generation to generation, play a vital role in disease management. They heavily depend on this knowledge of the traditional system due to poverty, and lack of modern medical facilities, so this information is restricted to rural areas (Sandhya et al., 2006; Ibrar et al., 2007).

The uses of plants as alternative medicine are very common and almost documented both in monoherbal and polyherbal forms in the study area Adnan et al. (2014a), Mussarat et al. (2014), Adnan et al. (2018), Malik et al. (2018), Mussarat et al. (2021) however, only a few reports are available on animal uses from Pakistan (Arshad et al., 2014; Ali et al., 2017; Altaf et al., 2017; Altaf et al., 2018; Shams et al., 2019; Altaf et al., 2020; Ahmad et al., 2021). The documentation of floral and faunal traditional recipes is indispensable before its depletion due to increasing urbanization, modernization, and industrialization. It is essential to report the traditional knowledge regarding plant and animal uses of individual human communities in unexplored regions. Moreover, with the increasing challenge of microorganisms' resistance against existed allopathic medicines, there is a dire need to check new combinations of natural constituents with additive and synergistic effects. Therefore, the study has been planned with the objectives to document 1) recipes comprised of animals, animal parts, or animal products 2) recipes comprised of both plant and animal parts/products used by the residents of the southern region of Khyber Pakhtunkhwa, Pakistan, and 3) the highly preferred recipes by quantitative indices. This is may be the first time reported study in the selected area to document traditionally used medicinal animal species and animal-plant recipes. The results of the study may be helpful in the conservation of traditional knowledge and identification of new species as a potential source of alternative and complementary medicine.

\section{METHODS}

\section{Study Area}

This study documents the ethnomedicinal data in three major remote areas (Dera Ismail Khan (D. I. Khan), Bannu, and Lakki Marwat) of Khyber Pakhtunkhwa. D. I. Khan is an area of 7,326 square kilometers and located between $31^{\circ} 15^{\prime}$ and $32^{\circ} 32^{\prime} \mathrm{N}$ latitude and between $70^{\circ} 11^{\prime}$ and $71^{\circ} 20^{\prime} \mathrm{E}$ longitude (Mussarat et al., 2014). Bannu consists of a total area of 877 square kilometers, with a population of 2,044,074. It lies within the Karakoram mountain ranges between $32^{\circ} 43^{\prime}$ to $33^{\circ} 06^{\prime} \mathrm{N}$ latitude and $73^{\circ} 20^{\prime}$ to $70^{\circ} 07^{\prime} \mathrm{E}$ longitude. The population is $100 \%$ ethnic Pashtun with different casts and different accents i.e. Bannuchi, Wazir, Dawar, Marwat and Bangash. The district forms a basin drained by the Kurram River and Gambila River (Tochi River) which originates from the hills of Waziristan. The Kurram River enters the district from the northwest and from there; it runs towards the south-east, then south into Lakki Marwat (Shaheen et al., 2017). Lakki Marwat is located between $32^{\circ} 161^{\prime} \mathrm{N}$ latitude and $70^{\circ} 191^{\prime} \mathrm{E}$ longitude at an altitude of 200-1,000 $\mathrm{m}$ above sea level (Figure 1). Different ethnic groups living in the study area majority of them were Pashtun with a little difference in their accent. Urdu and English were also spoken and understood by a large number of people. Those living in the urban area possess good socio-economic conditions, having a strong belief in traditional medicine for their primary health care due to the side effects of allopathic medicines. The people living in villages have low-income status and low educational, occupational, and financial level and depend on flora and fauna for their income 


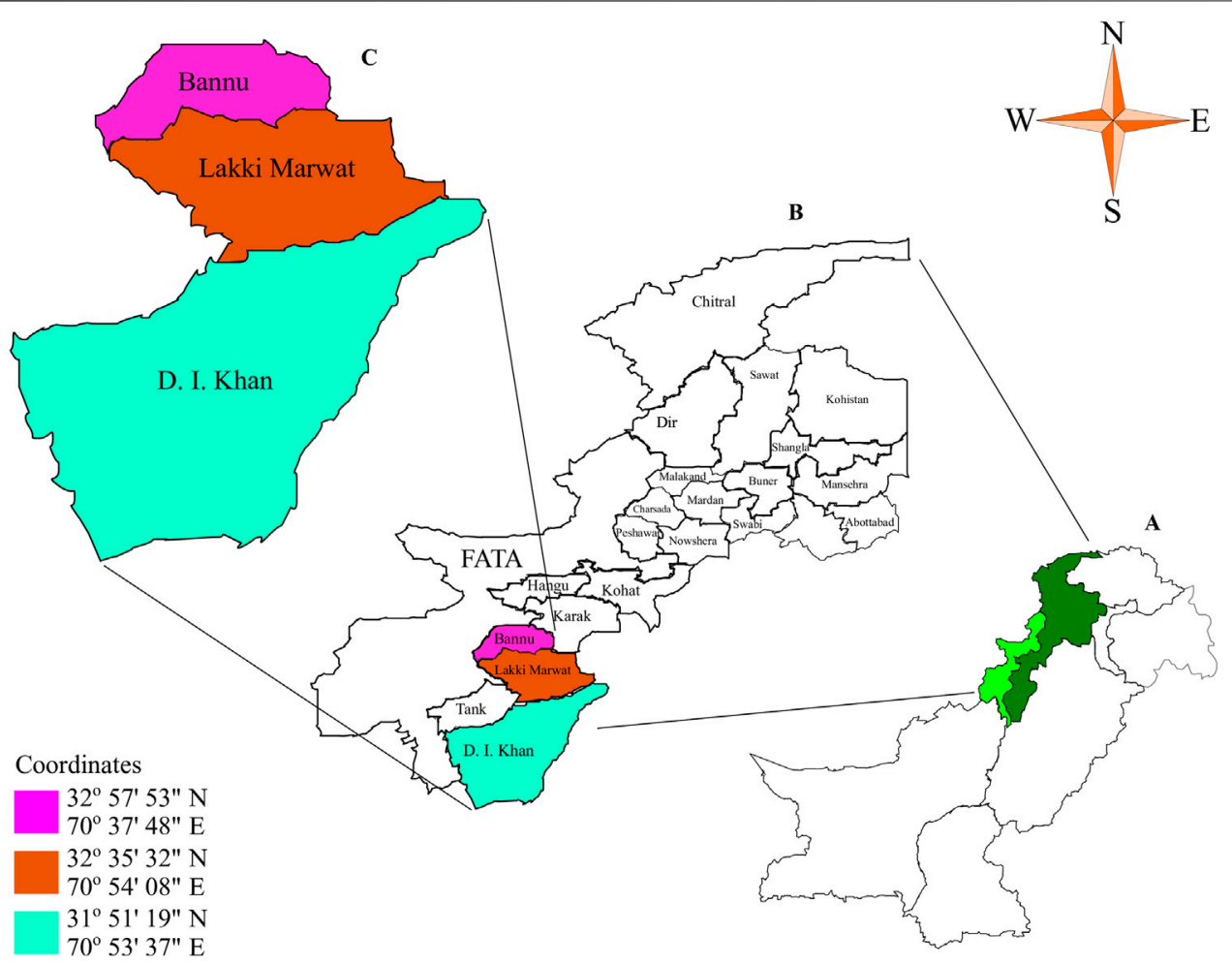

FIGURE 1 | Map of the study area (A) Pakistan (B) Khyber Pakhtunkhwa (C) selectiive districts in southern Khyber Pakhtunkhwa.

and primary health needs. These three regions were occupied with a diversity of animals and plants and most of the people of rural as well as urban regions depend upon plants and livestock. Being a rich diversity center, dominant, plant and animal species are Vachellia nilotica (L.) P.J.H. Hurter \& Mabb Calotropis procera (Aiton) W.T. Aiton, Withania coagulans (Stocks) Dunal, Zizyphus, and cattle, goat, common quail, and grey francolin, respectively.

\section{Ethical Approval}

This research study was duly approved by the Ethical Research Committee of Kohat University of Science and Technology (KUST) Ref. No. KUST/Ethical Committee/17-12 before the field survey concerning ethnomedicinal data collection and intellectual property rights of local inhabitants. Moreover, ethical guidelines of the International Society of Ethnobiology (http://www.ethnobiology.net) were also followed during the field survey.

\section{Field Survey and Data Collection}

The data collection was carried out from 2017 to 2018. Semistructured questionnaires were designed to collect ethnomedicinal knowledge of local people about animals and plants. Questionnaires and interviews were conducted to document traditional uses of the animal, animal parts, animal-derived product(s), and animal-plant recipes. Before interviewing, a discussion was held with the informants through the assistance of local elders to elaborate on the objective of the study. This was done to clarify the purpose and build the confidence of the respondents to provide reliable information without any suspicion. Data were collected from 185 local informants including farmers, housewives, teachers, and traditional health practitioners. Prior to data collection, oral, and written informed consent was taken from informants for publication. All informants voluntarily participated in the study. The selected informants were well-known in the community due to their practice of using animals and plants as medicines for their primary health care. These local respondents of the regions were aged between 21 and 79 years. Data were collected in the local language Pashto and Saraiki. There was no need for an interpreter during data collection.

\section{Animal and Plant Species Identification}

Mammals, birds, reptiles, and fish species were photographed and recognized using field guides "Mammals of Pakistan" Roberts (2005a); Roberts (2005b), "Birds of Pakistan" Roberts (1991), "Amphibian and Reptiles of Pakistan" Khan (2006), and "Freshwater Fishes of Pakistan" Mirza (1975). Animal species were thoroughly identified with the help of standard taxonomic keys and available published literature (Day, 1889; Pocock, 1900; Mallon, 1991; Roberts, 1997; Mirza and Wasiq, 2007). Invertebrates and other small animals were captured, identified and after that, they were released again. While large animal species were recognized in the field as per the respective folk description and subsequently with the aid of photo snaps. These photographs were submitted in the Taxonomy Lab of the Department of Zoology, KUST, 


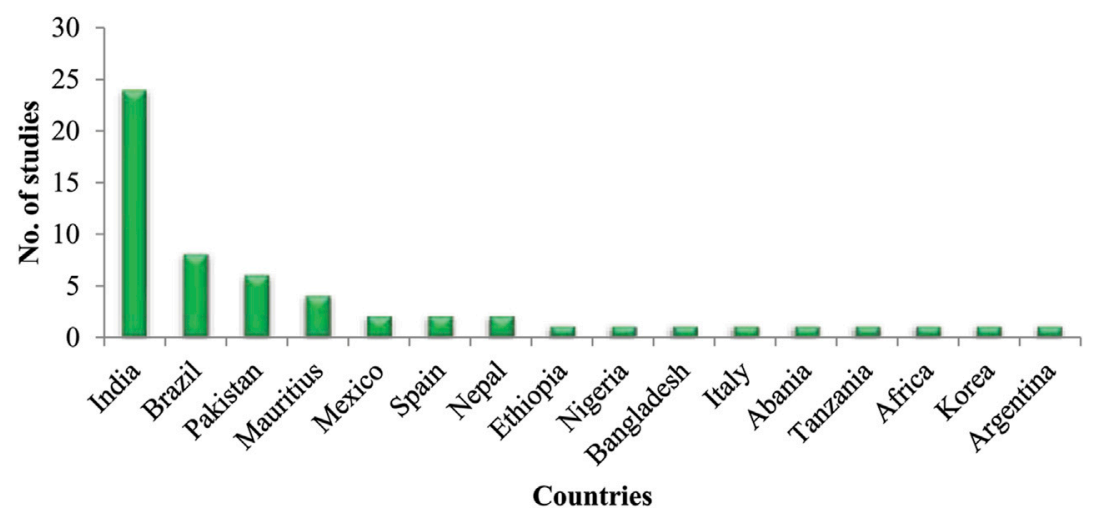

FIGURE 2 | Number of ethnozoological studies conducted throughout the world.

Kohat. Moreover, the species scientific names were checked and corrected by using the Global Biodiversity Information Facility (https://www.gbif.org) and Catalogue of Life (https://www. catalogueoflife.org).

Plants used in combination with animal species in traditional therapy were collected from the study area and identified at the Department of Botanical and Environmental Sciences, KUST, Kohat and submitted to the herbarium. Voucher numbers were given in the table with each plant species. Plant name correction and their synonym were checked online from "medicinal plant name services-KEW” (http://mpns.kew.org/mpns-portal); "world flora online" (http://www.plantsoftheworldonline.org), and "the plant list" (http://www.theplantlist.org).

\section{Data Organization}

The collected data on ethnomedicinal animals, plants, and ethnography of the respondents were organized into tables and figures. Animal products and parts were categorized into meat, milk, fat, liver, hoofs, bone, spleen, hide, eggs, and the whole animal, etc. Plant parts were categorized into leaves, roots, stem, whole plant, seeds, fruit, and flower, etc.

\section{Data Quality Assurance}

For data verification, each informant was visited at least three times. Only validated and relevant data were subjected to further organization and analysis process. Moreover, authors were trained to collect medicinal plants and animals from the area as well as combination therapy formulation-related information, their uses, doses and concentrations, disease treated, point out missing information, and duplication of materials to maintain data quality.

\section{Literature Search}

A literature search was performed for retrieving published articles about the traditional use of animals as medicine. Articles published between 1970 and 2021 were retrieved by using different key words like "ethnobiology," "traditionally used animals," "ethnozoology", "animal use as medicine," and "ethnomedicinal application of animals" in different search engines. Studies that reported the use of animals as medicine were selected and included in this study. Country name and number of studies in each country were counted and a graph comparison was shown (Figure 2).

\section{Quantitative Analysis}

Data on ethnomedicinal uses and cultural values of animal products or parts and their mixture with plants were analyzed using various indices such as frequency of citation (FC), informant consensus (FIC), and fidelity level (FL) to find the highly preferred species in the area statistically.

\section{Frequency of Citation (FC)}

FC is the number of local respondents who reported ethnomedicinal uses of each animal species (Hoffman and Gallaher, 2007).

\section{Informant Consensus (FIC)}

FIC on the reported cures of a given group of ailments was calculated as an informant consensus factor. FIC within a community designates the widely used species and thus helps in the selection for phytochemical and pharmacological studies. Reported ailments were grouped into major categories. FIC values are high when one or few animals are reported by many informants to treat a specific ailment, while low FIC values indicate that informants do not agree over which animal to use (Hoffman and Gallaher, 2007).

The FIC can be calculated as; FIC = nur - nt/nur -1 .

Where FIC = Informants consensus factor, nur = number of used citations in each category, and $\mathrm{nt}=$ number of species used.

\section{Fidelity Level (FL)}

Fidelity level (FL) helps recognize the most favored species used to treat a special ailment by the respondents (Hoffman and Gallaher, 2007). FL value of highly preferred animals is greater than the value of less preferred animals. FL value is always calculated in terms of the informant's percentage claiming the use of a definite species for the same ailment. The FL values indicate the importance of certain species for a particular purpose. The reported diseases were grouped into major classes for the calculation of FL values. FL values were calculated as; 
TABLE 1 | Socio-demographic characteristics of the respondents $(n=185)$ in ethnobiological data collection.

\begin{tabular}{|c|c|c|}
\hline Variables & Total & Percentage (\%) \\
\hline \multicolumn{3}{|l|}{ Gender } \\
\hline Male & 68 & 36.75 \\
\hline Female & 117 & 63.24 \\
\hline \multicolumn{3}{|l|}{ Age groups } \\
\hline $21-29$ & 15 & 8.10 \\
\hline 30-39 & 35 & 18.91 \\
\hline $40-49$ & 50 & 27.02 \\
\hline $50-59$ & 32 & 17.29 \\
\hline $60-69$ & 45 & 24.32 \\
\hline $70-79$ & 8 & 4.32 \\
\hline \multicolumn{3}{|l|}{ Education level } \\
\hline Illiterate & 60 & 32.43 \\
\hline Primary & 35 & 18.91 \\
\hline College & 45 & 24.32 \\
\hline University & 45 & 24.32 \\
\hline \multicolumn{3}{|l|}{ Occupation } \\
\hline \multicolumn{3}{|l|}{ Females } \\
\hline Housewives & 45 & 24.32 \\
\hline Primary teacher & 40 & 21.62 \\
\hline Secondary teachers & 32 & 17.29 \\
\hline \multicolumn{3}{|l|}{ Males } \\
\hline Farmers & 30 & 16.21 \\
\hline Primary teachers & 15 & 8.10 \\
\hline Secondary teachers & 10 & 5.40 \\
\hline Traditional Practitioner & 13 & 7.02 \\
\hline
\end{tabular}

$\mathrm{FL}=\mathrm{Ip} / \mathrm{Iu} \times 100$. Where Ip indicated the number of informants who reported animal utilization for a specific disease and $\mathrm{Iu}$ is the total number of informants who mentioned the same animal for any disease. It is assumed that those medicinal animals which are used frequently by most respondents for the same disease category are more likely to be scientifically effective (Hoffman and Gallaher, 2007).

\section{RESULTS}

\section{Demographic Profile of Respondents}

The local communities of the remote areas have substantial awareness concerning ethnomedicines. During the survey, both male $(36.75 \%)$ and female (63.24\%) respondents of different age groups were questioned (Table 1). The findings depicted that respondents having age $>40$ years secured a high percentage $(n=$ $135,73 \%)$ as compared to respondents <40 years with a percentage of $(n=50,27 \%)$. The informants were mostly literate comprising of intermediate, university (24.3\% each), and primary level (18.9\%) of education. The occupation-wise order of the respondents was: teachers (52.43\%), farmers (16.21\%), housewives $(24.32 \%)$, and practitioners (7.02\%).

\section{Ethnomedicinal Use of Animals}

The present study documented 32 animal species used by the local communities for curing 37 diseases (Table 2). These animal species were comprised of both vertebrates ( 24 species) and invertebrates (8 species). Thirteen species were belonging to class Mammalia, eight to Aves, five to Insecta, two to Arachnida, two to Reptilia, one to Pisces, and one to Annelida (Figure 3). Animals such as Felis catus, Camelus dromedarius, Bos taurus, Equus asinus, Capra hircus, Canis aureus, Paraechinus micropus, Oryctolagus cuniculus, Funambulus palmarum were used for treating different types of diseases including epilepsy, cancer, hepatitis, night blindness, whooping cough, asthma, and brain hemorrhage among others.

\section{Ethnomedicinal Use of Animal Products/ Parts}

The most widely utilized animal products/parts were meat, used in 19 recipes followed by whole animal and milk, used in nine recipes. While other animal products/parts including fat, oil, hide, liver, eggs, bones, and butter were among the least used products (Figure 4). The meat of different animal species such as goat, rabbit, monkey, and Indian palm squirrel was used for treating diseases like hepatitis C, cancer, epilepsy, asthma, and weakness. Similarly, eggs of chicken and pigeon were utilized to treat blood pressure, fever, cough, joint pain and chest infection. Milk of camel, cattle, cat, and the donkey was reported for several ailments and believed to be effective in relieving joints and back pain, gastric pain, treat cancer, paralysis, whooping cough, and reduce obesity. Among the least used products/ parts, animals' fat and oil were practiced to treat baldness, joint and muscle aches, and for sexual enhancement.

\section{Phytozootherpy Recipes}

This is the first reported study from the area describing the healing practices of animal-plant mixture recipes. A total of 17 plants belonging to 15 families were used in combination with animal parts/products. The most commonly used botanical family was Piperaceae (31\%) followed by Apiaceae (27\%), Brassicaceae, Solanaceae, Zingiberaceae and Arecaceae (5\%) each. The notable plant species were Curcuma longa L., Piper nigrum L., Coriandrum sativum L., Brassica rapa L., and Phoenix dactylifera L. (Table 3). Seeds were mostly used plant parts in animal-plant mixture recipes following fruits, oil, and rhizome. While bark, peel, and leaves were the least commonly used plant parts (Figure 5).

\section{Modes of Preparation and Application}

Mostly practiced mode of administration was drinking used in 22 recipes followed by eating, massaging, and wearing used in 16, 9, and 8 recipes, respectively. Other modes like tying and sucking contributed in less than three recipes (Figure 6). Some of the traditional medicine (liquids and solids) was taken orally, while others were applied topically like, animal hides were worn to treat fever and bones were tied for healing purposes. In the recipes' preparation, additives like water, honey, oil, milk, sugar, salt, and colors were also used (Table 3 ).

\section{Quantitative Analysis}

Animal species that were used by the maximum number of respondents to treat various diseases secured a high FC value. In the current findings, the FC values for using animal-based recipes ranged from 1 to 28 , while for animal-plant recipes they ranged from 2 to 47 . In animal-based recipes chicken $(\mathrm{FC}=28)$, cattle $(\mathrm{FC}=22)$, and Asian honey bee $(\mathrm{FC}=21)$ were the most commonly used species. While ants, ostrich, and jackal were with 
TABLE 2 | Medicinal uses of animal species and their body parts/products in southern regions of Khyber Pakhtunkhwa (Pakistan).

Animal zoological name/ English/Local

\section{Area}

Additives body part

used

\section{Recipe and disease treated}

\begin{tabular}{cc} 
Dosage and treatment duration \\
\hline Children
\end{tabular}

FC

\section{Mammalia}

Felis catus Linnaeus, 1758/

Cat/Billi

Camelus dromedarius

Linnaeus, 1758/Camel/

Oontni/Usha

Bos taurus Linnaeus, 1758/
Cow/Gaae, Ghwa
1758/Donkey/Kaaligadhi,

\section{D.I. Khan}

D.I. Khan

Milk

Milk

Water

NA

Bone of knee NA

Bannu, Lakki Marwat

D.I. Khan

.

Liver

Tongue

Oil

Omasum

Water

Bannu
Equus asinus Linnaeus, Khra

D.I. Khan,

Lakki Marwat

Bannu

Bannu, D.I

Khan, Lakki

Marwat

Capra hircus Linnaeus,

1758/Goat/Bakri/Wooza
D.I. Khan,

Lakki Marwat

\section{butter}

Urine

Bones

Milk

Milk

(1)

Liver

Skin

Hide

Head meat

Bannu, D.I. Milk

Khan

D.I. Khan

D.I. Khan

Skin

Ankle bone

NA

1758/Jackal/Geedar

Herpestes edwardsi E.

Geoffroy Saint-Hilaire, 1818/

Mongoose/Neola

Macaca mulatta

Zimmermann, 1780/

Monkey/Bander, Beezo

Paraechinus micropus Blyth, Lakki Marwat Meat

1846/Hedgehog/

Kharpusht, Jeggay

NA

NA
Milk is administered orally for epilepsy

Milk is administered orally for joint and back pain, to reduce obesity, and cure cancer

Bone is buried in the earth to avoid

termites' nuisance at home

Milk is administered orally to cure

Hepatitis B and C

Butter is prescribed for bone fracture

The cooked spleen is used for drooling in children and to strong teeth

The udder is prescribed for lactating

mothers to increase milk quantity

One cup of curd is mixed with 2 eggs and prescribed for hair growth

For storage of water

Blood of cow, goat, camel, buffalo, and sheep is used to induce fertility and increase the number of fruit on plants

Fried liver is used to treat night blindnes

The tongue is cooked and used to treat stuttering

Omasum is cooked and used for

digestive problems (pain, gas, and indigestion)

Cow milk is mixed with butter and used to relieve gastric pain

Urine is used for whooping cough

Mix any

color with it

Donkey bones are crushed to make powder and administered orally to cure epilepsy patients

Milk is used for whooping cough and asthma

Fresh milk is administered orally for blisters in the mouth and used topically on the head for dizziness

Goat liver is fried in a frypan to obtain the extract for curing night blindness

The skin is heated up and tied around the arm to heal bone fracture

Goat hide is used to relieve joints pain Once a day

The head meat is used for the treatment Once a day of hepatitis $\mathrm{C}$

Female milk is heated up and used to One time for

cure cough, flu, and as a drop in the ear of 3 days at night children to relieve earache

Skin in the form of a "hat" is used for brain NA hemorrhage

The bone is tied to the thighs of a pregnant woman to ease delivery.

Mongoose is sacrificed and cooked with pumpkin to cure joint pain

Meat is cooked properly and used for severe cough

NA

NA

Not used

Once a day

Once a week

NA

NA

Not used

Not used

NA

For 7 days

NA

Half glass once a day week

NA

Half glass for a week

4-5 spoons

NA

For 1 week

nce a day

NA

Meat is cooked and used for the
One time

NA
Not used

One cup per day Two cups per day

Half cup twice a

Once a day

Once a week

Twice a week

Once a week

Not used Not used

NA

NA

For 7 days regularly

One glass a day

Half cup twice a week

NA

One glass at night

for 1 week

5-6 spoons

One drop once

a day

For 1 week

NA

NA

NA treatment of cancer

\section{1 week}

One time

One time

NA 
TABLE 2 | (Continued) Medicinal uses of animal species and their body parts/products in southern regions of Khyber Pakhtunkhwa (Pakistan).

\begin{tabular}{|c|c|c|c|c|c|c|c|}
\hline \multirow{2}{*}{$\begin{array}{l}\text { Animal zoological name/ } \\
\text { English/Local }\end{array}$} & \multirow[t]{2}{*}{ Area } & \multirow{2}{*}{$\begin{array}{l}\text { Product/ } \\
\text { body part } \\
\text { used }\end{array}$} & \multirow[t]{2}{*}{ Additives } & \multirow[t]{2}{*}{ Recipe and disease treated } & \multicolumn{2}{|c|}{ Dosage and treatment duration } & \multirow[t]{2}{*}{ FC } \\
\hline & & & & & Children & Adults & \\
\hline $\begin{array}{l}\text { Oryctolagus cuniculus } \\
\text { Linnaeus, 1758/Rabbit/ }\end{array}$ & Bannu & Skin & NA & $\begin{array}{l}\text { Wearing of rabbit skin in hand or foot is } \\
\text { used to relieve bone pain }\end{array}$ & NA & One time & 4 \\
\hline Khargosh/Soya & Lakki Marwat & Meat & Oil & Meat is used to treat asthma & Once a day & Twice a day & \\
\hline \multirow[t]{3}{*}{$\begin{array}{l}\text { Ovis aries Linnaeus, 1758/ } \\
\text { Sheep/Bhaer, Mazh }\end{array}$} & Bannu & Skin & NA & $\begin{array}{l}\text { Wearing of sheep skin is used for the } \\
\text { treatment of severe cough, fever, and } \\
\text { paraplegia }\end{array}$ & NA & One time & 5 \\
\hline & D.I. Khan & Skin & NA & $\begin{array}{l}\text { Skin is worn like clothes to treat muscle } \\
\text { and joint pain as well as winter fever }\end{array}$ & For a week & For a week & \\
\hline & Lakki Marwat & Wool & NA & $\begin{array}{l}\text { The sheep wool is burnt in the fire to make } \\
\text { ash and used for healing wounds }\end{array}$ & One time daily & One time daily & \\
\hline $\begin{array}{l}\text { Funambulus palmarum } \\
\text { Linnaeus, 1758/Squirrel/ }\end{array}$ & Bannu & Meat & Oil & $\begin{array}{l}\text { Fried meat of squirrel in oil is used to treat } \\
\text { epilepsy patient and relieve pain }\end{array}$ & NA & $\begin{array}{l}\text { Once a day for } \\
1 \text { week }\end{array}$ & 2 \\
\hline \multirow[t]{2}{*}{ Gulehri, Korhibili } & & Tail & Oil & $\begin{array}{l}\text { Fried tail of squirrel in oil is used for hair } \\
\text { growth }\end{array}$ & NA & $\begin{array}{l}\text { Two times in a } \\
\text { week }\end{array}$ & \\
\hline & D.I. Khan & Oil/fat & NA & $\begin{array}{l}\text { Oil of squirrel is used for the treatment of } \\
\text { baldness especially in male }\end{array}$ & NA & Once a day & \\
\hline \multicolumn{8}{|l|}{ Aves } \\
\hline $\begin{array}{l}\text { Corvus splendens Vieillot, } \\
\text { 1817/Crow/Kaan, Laagra }\end{array}$ & $\begin{array}{l}\text { Bannu, D.I. } \\
\text { Khan }\end{array}$ & Tongue & Salt & $\begin{array}{l}\text { The tongue of a crow is fried and eaten for } \\
\text { stuttering or crow's drinking water is } \\
\text { given to a child }\end{array}$ & NA & $\begin{array}{l}\text { One time a day for } \\
3-5 \text { days }\end{array}$ & 4 \\
\hline $\begin{array}{l}\text { Anas platyrhynchos } \\
\text { Linnaeus, 1758/Duck/ }\end{array}$ & D.I. Khan & Meat & Salt and oil & $\begin{array}{l}\text { Cooked meat is used for anemia and } \\
\text { kidney problems }\end{array}$ & NA & Once a week & 6 \\
\hline \multirow[t]{2}{*}{ Batakh } & & Fat & Salt & $\begin{array}{l}\text { Fat is used for relieving piles pain and } \\
\text { healing of injuries }\end{array}$ & NA & NA & \\
\hline & & Liver & Oil & $\begin{array}{l}\text { Cooked liver is used to speed up } \\
\text { hematopoiesis for curing anemia }\end{array}$ & NA & NA & \\
\hline \multirow[t]{9}{*}{$\begin{array}{l}\text { Gallus gallus Linnaeus, } \\
\text { 1758/Chicken/Murghi }\end{array}$} & Lakki Marwat & Egg & NA & $\begin{array}{l}\text { Egg is boiled and whole yolk is removed. } \\
\text { The yolk is cooked unless and until the oil } \\
\text { come out of it. This oil is used for joints } \\
\text { pain, hair fall, and body massage }\end{array}$ & NA & Two times daily & 28 \\
\hline & & & Milk & $\begin{array}{l}\text { Raw egg is mixed with milk. It has great } \\
\text { nutritional value and is used for blood } \\
\text { pressure }\end{array}$ & NA & One time & \\
\hline & & Meat & NA & $\begin{array}{l}\text { Meat is cooked in water to make soup. It } \\
\text { is used for cough, fever, asthma, and } \\
\text { weakness }\end{array}$ & Once a day & Once a day & \\
\hline & & Egg yolk & NA & $\begin{array}{l}\text { Egg yolk is separated and applied on the } \\
\text { head of children for early tooth eruption }\end{array}$ & One time daily & NA & \\
\hline & & Fat & NA & $\begin{array}{l}\text { Hen fat oil is extracted through cooking. } \\
\text { The oil is then used for chest pain and ear } \\
\text { pain in children }\end{array}$ & $\begin{array}{l}\text { Two times daily in } \\
\text { case of chest } \\
\text { pain }\end{array}$ & NA & \\
\hline & Bannu & Eggs, meat & $\begin{array}{l}\text { Sugar, some } \\
\text { spices }\end{array}$ & $\begin{array}{l}\text { Raw eggs are mixed with boiled milk to } \\
\text { treat cough. Make a sweet dish of eggs } \\
\text { and is used for backache. Soup is used } \\
\text { for chest infections. Hen fat is used for } \\
\text { tooth eruption }\end{array}$ & $\begin{array}{l}\text { One egg in one } \\
\text { cup of milk at } \\
\text { night }\end{array}$ & $\begin{array}{l}\text { One egg in one cup } \\
\text { of milk at night }\end{array}$ & \\
\hline & D.I. Khan & Skin & NA & $\begin{array}{l}\text { Skin is used for treatment of blisters and } \\
\text { pimples }\end{array}$ & NA & Once a day & \\
\hline & & Fat & NA & $\begin{array}{l}\text { Topically used on gums of children to } \\
\text { easy tooth eruption }\end{array}$ & Twice a day & NA & \\
\hline & & Eggshell & NA & $\begin{array}{l}\text { Eggshell is hanged using a piece of } \\
\text { thread to avoid lizard nuisance at home } \\
\text { and in room, etc. }\end{array}$ & Not used & Not used & \\
\hline $\begin{array}{l}\text { Struthio camelus Linnaeus, } \\
\text { 1758/Ostrich/Shutar murgh }\end{array}$ & D.I. Khan & Fat & NA & $\begin{array}{l}\text { Fat is topically applied on hands and feet } \\
\text { of children for walking at an early age }\end{array}$ & Once a daily & NA & 1 \\
\hline $\begin{array}{l}\text { Columba livia J. F. Gmelin, } \\
\text { 1789/Pigeon/Kabooter/ }\end{array}$ & Bannu & Meat & Salt & $\begin{array}{l}\text { Pigeon meat is used for early onset of } \\
\text { puberty in young girls }\end{array}$ & NA & $\begin{array}{l}\text { One time at night } \\
\text { daily for } 1 \text { week }\end{array}$ & 4 \\
\hline \multirow[t]{2}{*}{ Kawtara } & D.I. Khan & Egg & NA & $\begin{array}{l}\text { Boiled eggs are used to treat children for } \\
\text { stammering }\end{array}$ & $\begin{array}{l}\text { One egg per day } \\
\text { for almost } \\
1 \text { week }\end{array}$ & NA & \\
\hline & Bannu & Droppings & Mother milk & & & NA & 5 \\
\hline
\end{tabular}

(Continued on following page) 
TABLE 2 | (Continued) Medicinal uses of animal species and their body parts/products in southern regions of Khyber Pakhtunkhwa (Pakistan).

\begin{tabular}{|c|c|c|c|c|c|}
\hline \multirow{2}{*}{$\begin{array}{l}\text { Animal zoological name/ } \\
\text { English/Local }\end{array}$} & \multirow[t]{2}{*}{ Area } & \multirow{2}{*}{$\begin{array}{c}\text { Product/ } \\
\text { body part } \\
\text { used }\end{array}$} & \multirow[t]{2}{*}{ Additives } & \multirow[t]{2}{*}{ Recipe and disease treated } & Dosage and treatment duration \\
\hline & & & & & Children \\
\hline
\end{tabular}

Passer domesticus

Linnaeus, 1758/House

sparrow/Chirya, Murghya

Reptilia

Saara hardwickii Gray, 1827/Indian spiny-tailed

lizard/Sanda

$\begin{array}{llll} & \text { D.I. Khan } & \text { Fat } & \text { NA } \\ \begin{array}{l}\text { Echis carinatus Schneider, } \\ \text { 1801/Snake/Manger }\end{array} & \text { Bannu } & \text { Whole animal } & \text { NA } \\ \begin{array}{l}\text { Pisces } \\ \text { Labeo rohita Hamilton, } \\ \text { 1822/Rohu/Machli, Kab }\end{array} & \text { Bannu } & \text { Liver } & \text { NA } \\ & \begin{array}{l}\text { D.I. Khan } \\ \text { Lakki Marwat }\end{array} & \text { Bones } & \text { Honey } \\ & & \end{array}$

Insecta

Ochetellus glaber Mayr

1862/Ant/Mizhai

Apis cerana Fabricius, 1793/

Shehad Makhi/Asian honey

bee/Muchya

Sceliphron caementarium

Drury, 1773/Mud wasp/

Girain

Musca domestica Linnaeus,

1758/Housefly/Mach

\section{Arachnida}

Orthochirus pallidus

Pocock, 1897/Scorpian/

Bichoo, Larham

\begin{tabular}{|c|c|c|c|}
\hline Orthochirus pallidus & D.I. Khan & Whole animal & Oil \\
\hline & Bannu & Whole animal & NA \\
\hline Stegodyphus pacificus & D.I. Khan & Web & Water \\
\hline
\end{tabular}

\section{Annelida}

Hirudinaria manillensis

Lessom/Leech/Keera, Jalam
Lakki Marwat Fat

NA

$$
\begin{array}{ll}
\text { Oil } & \text { NA } \\
\text { Gall bladder } & \text { NA }
\end{array}
$$

Bannu

Bannu, D.I.

Khan

D.I. Khan

Mud house Water

Whole insect Chicken

soup

Lakki Marwat Whole insect Sugar

Bannu, D.I. Whole insect NA Khan
Droppings of sparrows is mixed with mother milk and administered orally to children for the treatment of diarrhea and to relieve abdominal pain

Fat is converted into oil and applied topically for joints pain, sexual enhancement, body massage, and muscle ache

Sanda oil is used topically for muscle and NA bone pain

Snake is boiled to make soup and is used for the treatment of cancer and all noncurable diseases

Cod liver oil is used for the treatment of asthma, rickets, joints pain and skin fairness

Fish skeleton is cooked unless and until it turns black and then ground to make powder of it. A small amount of powder is mixed with one spoon of honey to relieve cough and chest pain

Oil is topically applied for joint pain

The gall bladder is dried up for a long period in a shady place and used for kidney pain and removal of kidney stones

Mud house paste is mixed with water and applied topically for curing mumps

Honey is mixed with milk and used as an anti-venom

One teaspoon of honey is mixed with two teaspoons of milk and used at night on the face for freshness and fairness

Mud house is mixed with water and used for vomiting

Forty houseflies are mixed with chicken soup to treat malaria

Houseflies are mixed with sugar to treat typhoid

Scorpion is cooked in oil to make a fine mixture locally called "roghan" and used topically for bell's palsy and paralysis Scorpion is killed and the poisonous part is removed and used to treat cancer and non-curable diseases

Cobweb is mixed in water and administered orally to treat vomiting in children

NA

NA

NA

NA

\section{Two spoons}

twice a day

Two times daily

Once time daily

Two teaspoons at 3 morning time for 3 days

One time daily

One time daily

Two times daily

Once a day

Thrice a day

night

Two times a day NA

Ten houseflies per day

NA

One time

Two times a day Two times a day

Human beings used leeches for sucking NA

One time

\section{C}




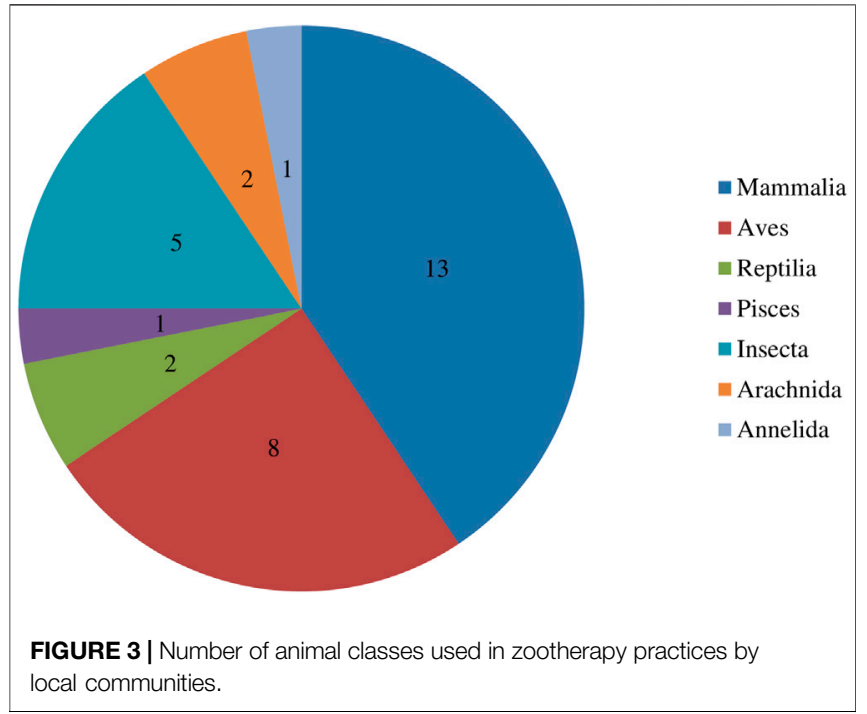

Fidelity level was calculated to recognize animal species that were most frequently and preferably used by the local population for curing certain ailments. The fidelity level ranged from 1 to $100 \%$. Animal species with the highest medicinal use in a particular area had a maximum fidelity level. Three animal species, pigeon $(\mathrm{FL}=80 \%)$, rabbit $(\mathrm{FL}=66.6 \%)$, and Asian honey bee $(\mathrm{FL}=45.94 \%)$ scored the highest, whereas goat scored the lowest $(\mathrm{FL}=13 \%)($ Table 5$)$.

\section{DISCUSSION}

Complementary and alternative medicine remained the basic source of primary health care at the doorstep of both urban and rural people. A large population of the world in developing as well as developed countries still depends upon ethnomedicine, despite a great advancement in modern health facilities and allopathic medicine.

The local population of the study area is mostly dependent on ethnomedicine as the first choice of treatment. No previous study has been reported to document traditionally used animal-based and animal-plant recipes from southern areas of Khyber Pakhtunkhwa. Therefore, this study was aimed to fulfill the knowledge gap of reporting ethnomedicine used in southern regions of Khyber Pakhtunkhwa with the main objectives to document 1) recipes comprised of animals, animal parts, or animal products 2) recipes comprised of both plant and animal parts/products and 3) the highly preferred recipes by quantitative indices.

People living in rural areas mostly have a strong belief and prefer traditional medicine (Adhikari et al., 2020). All the informants were having substantial knowledge of using ethnomedicines. Female respondents were found to be more familiar with the use of ethnomedicines than males. Mostly, females were involved in using ethnomedicine due to taking care of their children and families. Most of them were educated and had a strong belief in using ethnomedicine rather than allopathic medicine. The main reason, which female respondents stressed, was the associated side effects of allopathic medicine. The result was supported by earlier reports Mahomoodally et al. (2019) confirming females as the most predominant users of animal-based recipes. However, male respondents were more dominant and actively involved in using ethnomedicines in Nepal, India, and Ethiopia (Borah and Prasad, 2017; Kendie et al., 2018; Adhikari et al., 2020). The ratio of male to female respondents that were interviewed in the present study and those reported earlier may justify this difference.

The participants of age group above 40 years secured a high percentage and were predominantly involved in using ethnomedicines. A similar trend was observed in previous studies conducted in Nepal Adhikari et al. (2020), Ethiopia Kendie et al. (2018), India Borah and Prasad (2017), and Pakistan Altaf et al. (2018) indicating that elder respondents possessed more knowledge and experience regarding ethnomedicines. Mostly respondents stated that they acquired knowledge from their elders. This further strengthens the belief that transmission of folk medicine occurs from elder to younger individuals. In contrast, the possible reason for less ethnomedicinal awareness among youngers could be due to their intention towards urbanization and the least interest in ethnomedicine (Borah and Prasad, 2017). The informants were mostly literate and least being with a primary level of education. However, the illiteracy was also

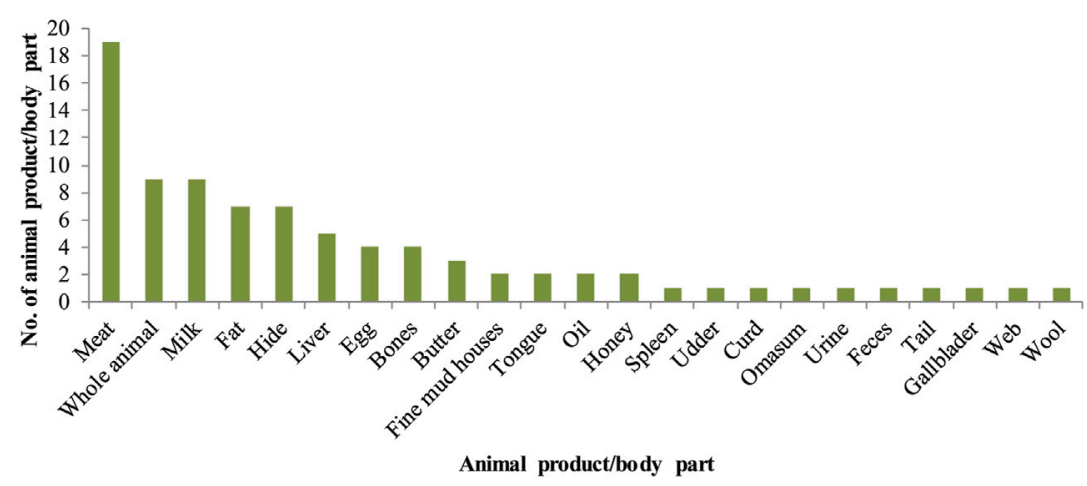

FIGURE 4 | Number of animal products or body parts used in ethnomedicine. 
TABLE 3 | Medicinal uses of animal-plant recipes in southern regions of Khyber Pakhtunkhwa (Pakistan).

\begin{tabular}{|c|c|c|c|c|c|c|c|}
\hline $\begin{array}{l}\text { Zoological } \\
\text { name/Local } \\
\text { name }\end{array}$ & Area & $\begin{array}{l}\text { Product/ } \\
\text { body part } \\
\text { used }\end{array}$ & $\begin{array}{c}\text { Botanical name/ } \\
\text { Local name/ } \\
\text { voucher no./Family }\end{array}$ & $\begin{array}{l}\text { Part } \\
\text { used }\end{array}$ & Additives & $\begin{array}{c}\text { Recipe and disease } \\
\text { treated }\end{array}$ & Dosage and treatment duration \\
\hline
\end{tabular}

Mammals

Bos taurus

Linnaeus, 1758/

Cow/Gaae, Ghwa
Curcuma longa L./ Rhizome Sugar

Haldi/KUH-1639/

Zingiberaceae

Phoenix dactylifera Fruit Sugar

L./Chwara/KUH-

359a/Arecaceae

Cicer arietinum L./

Citrus limon (L.)

Curd Mentha piperita L./

Butter

Bannu, Leg bones

D.I. Khan (Trotters)

Bannu Milk

Butter

Capra hircus

Linnaeus, 1758/

Goat/Bakri,

Wooza
Bannu, Meat

D.I. Khan
Piper nigrum L./Kali Seeds Salt, water mirch/KUH-462/

Piperaceae

Coriandrum sativum Seeds

L./Dhania/KUH-

331a/Apiaceae

Liver

Coriandrum sativum Seeds
Chana/KUH-323a/

Fabaceae

Osbeck/KUH-327a/

Niboo/Rutaceae

Podina/KUH-353a/

Lamiaceae

Piper nigrum L./Kali

mirch/KUH-462/

Piperaceae

Peganum harmala L./ Harmal/KUH-358a/

Nitrariaceae

Piper nigrum L./Kali

Mirch/KUH-462/

Piperaceae

Coriandrum sativum Seeds

L./Dhania/KUH-

331a/Apiaceae

Phoenix dactylifera

L./Kajoor/KUH-

359a/Arecaceae

Ricinus communis

L./Castor oil/KUH-

449a/Euphorbiaceae

Punica granatum L. Anar/KUH-448a/

Lythraceae

Seeds

Fruit

Leaves

Seeds

Seeds

NA

Seeds

Salt, water

add some spices, to make soup and is used to relieve backache and leg pain. It also used as a delicious and nutritious food

Cow's milk is mixed with four dates and

prescribed for the opening of heart valves

Two eggs, four spoons of Castrol oil are mixed with cow milk and is used at the time of delivery to relieve pain

Powder of dry peel of one Pomegranate is mixed with one jug of milk and two spoons of butter are used for the appendix and gastric pain

Boiled meat, a teaspoon of black pepper, one teaspoon of garam masala, salt are cooked to make soup and is used for the treatment of Hepatitis B L./Dhania/KUH331a/Apiaceae Piper nigrum L./Kali mirch/KUH-462/

Piperaceae some spices and used for the treatment of anemia
Salt, water treatment of cough and

Once a day Once a day
NA

NA

2-3 spoons 5-6 spoons after a

after a meal meal menses and use (one cup) for 3 days onwards. Repeat the same for each menstrual cycle for 3 months

Daily at night for 1 week

\section{One time One time a day}

a day

NA

One cup per day

One cup One cup daily at night night for 1 week

\section{NA One glass}

NA

One cup before breakfast and at night for 2 days

One cup daily for 8 per day 10 days daily for 15 days

3-4 pieces daily for almost 7-8 days
3-4 pieces daily for almost $7-8$ days daily at for 3-4 days

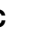


TABLE 3 | (Continued) Medicinal uses of animal-plant recipes in southern regions of Khyber Pakhtunkhwa (Pakistan).

\begin{tabular}{|c|c|c|c|c|c|c|c|c|c|}
\hline $\begin{array}{l}\text { Zoological } \\
\text { name/Local } \\
\text { name }\end{array}$ & Area & $\begin{array}{l}\text { Product/ } \\
\text { body part } \\
\text { used }\end{array}$ & $\begin{array}{c}\text { Botanical name/ } \\
\text { Local name/ } \\
\text { voucher no./Family }\end{array}$ & $\begin{array}{l}\text { Part } \\
\text { used }\end{array}$ & Additives & $\begin{array}{c}\text { Recipe and disease } \\
\text { treated }\end{array}$ & \multicolumn{2}{|c|}{ Dosage and treatment duration } & FC \\
\hline $\begin{array}{l}\text { Homo sapiens } \\
\text { Linnaeus, 1758/ } \\
\text { Human being/ } \\
\text { Insan }\end{array}$ & $\begin{array}{l}\text { Lakki } \\
\text { Marwat, } \\
\text { D.I. Khan }\end{array}$ & Hairs & $\begin{array}{l}\text { Brassica rapa L./ } \\
\text { Sarsoon/KUH-428a/ } \\
\text { Brassicaceae }\end{array}$ & Oil & Egg & $\begin{array}{l}\text { Hairs are dipped into a } \\
\text { mixture of Mustard oil } \\
\text { and egg for topical use to } \\
\text { relieve joints pain and } \\
\text { muscle ache }\end{array}$ & NA & Twice a day & 5 \\
\hline \multirow[t]{2}{*}{$\begin{array}{l}\text { Oryctolagus } \\
\text { cuniculus } \\
\text { Linnaeus, 1758/ } \\
\text { Rabbit/Khargosh }\end{array}$} & Bannu & Meat & $\begin{array}{l}\text { Solanum } \\
\text { lycopersicum L./ } \\
\text { Tmatar/KUH-469/ } \\
\text { Solanaceae } \\
\text { Capsicum annuum } \\
\text { L./Sabzmirch/KUH- } \\
\text { 468/Solanaceae }\end{array}$ & Fruit & Salt, water & $\begin{array}{l}\text { Cooked meat is used for } \\
\text { the treatment of } \\
\text { bronchial diseases }\end{array}$ & $\begin{array}{l}\text { Half cup of } \\
\text { soup per } \\
\text { day for } \\
4 \text { days }\end{array}$ & $\begin{array}{l}\text { One cup for almost } \\
2 \text { days }\end{array}$ & 5 \\
\hline & D.I. Khan & Meat & $\begin{array}{l}\text { Piper nigrum L./Kali } \\
\text { mirch/KUH-462/ } \\
\text { Piperaceae } \\
\text { Coriandrum sativum } \\
\text { L./Dhania/KUH- } \\
\text { 331a/Apiaceae }\end{array}$ & Seeds & Salt, water & $\begin{array}{l}\text { Meat is cooked with } \\
\text { some spices and salt for } \\
\text { treating Bell's palsy and } \\
\text { asthma }\end{array}$ & NA & One cup for 3 days & \\
\hline $\begin{array}{l}\text { Ovis aries } \\
\text { Linnaeus, 1758/ } \\
\text { Sheep/Bhaer, } \\
\text { Mazh }\end{array}$ & Bannu & Liver & $\begin{array}{l}\text { Piper nigrum L./Kali } \\
\text { mirch/KUH-462/ } \\
\text { Piperaceae } \\
\text { Coriandrum sativum } \\
\text { L./Dhania/KUH- } \\
\text { 331a/Apiaceae }\end{array}$ & Seeds & $\begin{array}{l}\text { Oil, salt, } \\
\text { water }\end{array}$ & $\begin{array}{l}\text { The liver is cooked with } \\
\text { spices and used to } \\
\text { increase the blood level }\end{array}$ & $\begin{array}{l}\text { Once a day } \\
\text { for a week }\end{array}$ & Once a day for a week & 5 \\
\hline \multicolumn{10}{|l|}{ Aves } \\
\hline \multirow[t]{2}{*}{$\begin{array}{l}\text { Gallus gallus } \\
\text { Linnaeus, 1758/ } \\
\text { Chicken/Chote } \\
\text { chooze }\end{array}$} & D.I. Khan & Meat & $\begin{array}{l}\text { Piper nigrum L./Kali } \\
\text { mirch/KUH-462/ } \\
\text { Piperaceae }\end{array}$ & Seeds & Salt, water & $\begin{array}{l}\text { Soup is used for the } \\
\text { anemic condition after } \\
\text { large injuries and } \\
\text { accidents }\end{array}$ & $\begin{array}{l}\text { Once a day } \\
\text { for a week }\end{array}$ & Once a day for a week & 8 \\
\hline & $\begin{array}{l}\text { Lakki } \\
\text { Marwat }\end{array}$ & & $\begin{array}{l}\text { Coriandrum sativum } \\
\text { L./Dhania/KUH- } \\
\text { 331a/Apiaceae }\end{array}$ & Seeds & & $\begin{array}{l}\text { Soup is used for the } \\
\text { chest infection, cough, } \\
\text { fever, asthma, and } \\
\text { weakness }\end{array}$ & $\begin{array}{l}\text { One time } \\
\text { a day }\end{array}$ & One time a day & 3 \\
\hline $\begin{array}{l}\text { Streptopelia } \\
\text { decaocto } \\
\text { Frivaldszky, 1838/ } \\
\text { Dove/Faakhta }\end{array}$ & Bannu & Meat & $\begin{array}{l}\text { Piper nigrum L./Kali } \\
\text { mirch/KUH-462/ } \\
\text { Piperaceae }\end{array}$ & Seeds & Salt, water & $\begin{array}{l}\text { Soup of dove meat, add } \\
\text { some spices and black } \\
\text { pepper is prescribed for } \\
\text { the treatment of cough } \\
\text { and early onset of } \\
\text { puberty in girls }\end{array}$ & $\begin{array}{l}\text { One cup at } \\
\text { night for } \\
\text { cough for } \\
3 \text { days }\end{array}$ & $\begin{array}{l}\text { One cup daily for } \\
1 \text { month }\end{array}$ & 6 \\
\hline \multirow[t]{2}{*}{$\begin{array}{l}\text { Columba livia J. F. } \\
\text { Gmelin, 1789/ } \\
\text { Pigeon/Kabooter, } \\
\text { Kawtara }\end{array}$} & Bannu & Meat & $\begin{array}{l}\text { Piper nigrum L./Kali } \\
\text { mirch/KUH-462/ } \\
\text { Piperaceae } \\
\text { Coriandrum sativum } \\
\text { L./Dhania/KUH- } \\
\text { 331a/Apiaceae }\end{array}$ & Seeds & Salt, water & $\begin{array}{l}\text { Boiled meat of pigeon by } \\
\text { adding some spices is } \\
\text { used for the treatment of } \\
\text { measles and Bell's palsy }\end{array}$ & $\begin{array}{l}\text { Two times } \\
\text { per day for } \\
\text { 3-days }\end{array}$ & $\begin{array}{l}\text { 3-times per day for } \\
\text { almost } 1 \text { week }\end{array}$ & 16 \\
\hline & $\begin{array}{l}\text { Lakki } \\
\text { Marwat, } \\
\text { D. I. Khan }\end{array}$ & Meat & $\begin{array}{l}\text { Piper nigrum L./Kali } \\
\text { mirch/KUH-462/ } \\
\text { Piperaceae } \\
\text { Coriandrum sativum } \\
\text { L. Dhania/KUH- } \\
\text { 331a/Apiaceae }\end{array}$ & Seeds & Salt, water & $\begin{array}{l}\text { Soup of pigeons is very } \\
\text { effective in cough, } \\
\text { asthma, and paralysis }\end{array}$ & $\begin{array}{l}\text { One time } \\
\text { daily }\end{array}$ & One time daily & \\
\hline \multirow[t]{2}{*}{$\begin{array}{l}\text { Passer } \\
\text { domesticus } \\
\text { Linnaeus, 1758/ } \\
\text { House sparrow/ } \\
\text { Chirya, Murghya }\end{array}$} & D.I. Khan & Meat & $\begin{array}{l}\text { Piper nigrum L./Kali } \\
\text { mirch/KUH-462/ } \\
\text { Piperaceae } \\
\text { Coriandrum sativum } \\
\text { L./Dhania/KUH- } \\
\text { 331a/Apiaceae }\end{array}$ & Seeds & Salt, water & $\begin{array}{l}\text { The meat of sparrow is } \\
\text { boiled by adding some } \\
\text { spices is used for the } \\
\text { treatment of measles } \\
\text { and heart problems }\end{array}$ & $\begin{array}{l}\text { One cup for } \\
\text { almost 3- } \\
\text { days }\end{array}$ & As needed & 3 \\
\hline & $\begin{array}{l}\text { Lakki } \\
\text { Marwat }\end{array}$ & Blood & $\begin{array}{l}\text { Vicia lens (L.) Coss. } \\
\text { and Germ. Masoor } \\
\text { Daal/KUH-467/ } \\
\text { Leguminosae }\end{array}$ & Seeds & NA & $\begin{array}{l}\text { Ground pulses (powder) } \\
\text { is mixed with blood to } \\
\text { make pills and are used } \\
\text { for sexual enhancement }\end{array}$ & NA & NA & \\
\hline
\end{tabular}


TABLE 3 | (Continued) Medicinal uses of animal-plant recipes in southern regions of Khyber Pakhtunkhwa (Pakistan).

\begin{tabular}{|c|c|c|c|c|c|c|c|c|c|}
\hline $\begin{array}{l}\text { Zoological } \\
\text { name/Local } \\
\text { name }\end{array}$ & Area & $\begin{array}{l}\text { Product/ } \\
\text { body part } \\
\text { used }\end{array}$ & $\begin{array}{c}\text { Botanical name/ } \\
\text { Local name/ } \\
\text { voucher no./Family }\end{array}$ & $\begin{array}{l}\text { Part } \\
\text { used }\end{array}$ & Additives & $\begin{array}{c}\text { Recipe and disease } \\
\text { treated }\end{array}$ & Dosage an & d treatment duration & FC \\
\hline $\begin{array}{l}\text { Acridotheres tristis } \\
\text { Linnaeus, 1758/ } \\
\text { Myna/Maina, } \\
\text { Myna }\end{array}$ & Bannu & $\begin{array}{l}\text { Whole } \\
\text { animal }\end{array}$ & $\begin{array}{l}\text { Piper nigrum L./Kali } \\
\text { mirch/KUH-462/ } \\
\text { Piperaceae } \\
\text { Coriandrum sativum } \\
\text { L./Dhania/KUH- } \\
\text { 331a/Apiaceae }\end{array}$ & Seeds & $\begin{array}{l}\text { Oil, salt, } \\
\text { water }\end{array}$ & $\begin{array}{l}\text { Boiled meat of starling by } \\
\text { adding some spices and } \\
\text { is prescribed to those } \\
\text { children who have a } \\
\text { problem in speaking and } \\
\text { walking }\end{array}$ & $\begin{array}{l}\text { Half cup } \\
\text { per day for } \\
2 \text { days }\end{array}$ & NA & 3 \\
\hline \multicolumn{10}{|l|}{ Insecta } \\
\hline $\begin{array}{l}\text { Neoponera } \\
\text { venerae Forel, } \\
\text { 1922/Ant/Papeeli }\end{array}$ & D. I. Khan & $\begin{array}{l}\text { Whole } \\
\text { body }\end{array}$ & $\begin{array}{l}\text { Olea europaea L./ } \\
\text { Zaitoon/KUH-466/ } \\
\text { Oleaceae }\end{array}$ & Oil & Water & $\begin{array}{l}\text { Whole ant is cooked in } \\
\text { olive oil by adding some } \\
\text { water and is used as a } \\
\text { drop in the ear to treat } \\
\text { deafness }\end{array}$ & NA & NA & 2 \\
\hline \multirow[t]{2}{*}{$\begin{array}{l}\text { Apis cerana } \\
\text { Fabricius, 1793/ } \\
\text { Asian honey bee/ } \\
\text { Shehad ki Makhi/ } \\
\text { Muchya }\end{array}$} & Bannu & Honey & $\begin{array}{l}\text { Camellia sinensis (L.) } \\
\text { Kuntze KUH-464/ } \\
\text { Sabzchay/Theaceae } \\
\text { Curcuma longa L./ } \\
\text { Haldi/KUH-436a/ } \\
\text { Zingiberaceae }\end{array}$ & Rhizome & Milk & $\begin{array}{l}\text { A spoon of honey is } \\
\text { mixed with half spoon } \\
\text { turmeric and one glass of } \\
\text { milk is used for the } \\
\text { treatment of cough and } \\
\text { throat infection. Honey is } \\
\text { also mixed with green } \\
\text { tea to lose extra fat }\end{array}$ & $\begin{array}{l}\text { One cup at } \\
\text { night for } \\
1 \text { week }\end{array}$ & $\begin{array}{l}\text { One cup at night for 3- } \\
\text { days and Green tea } \\
\text { can be used daily }\end{array}$ & 16 \\
\hline & D.I. Khan & Honey & $\begin{array}{l}\text { Cinnamomum verum } \\
\text { J.Presl/KUH-463/ } \\
\text { Dar cheeni/ } \\
\text { Lauraceae }\end{array}$ & Bark & NA & $\begin{array}{l}\text { Powder of cinnamon } \\
\text { plant is mixed with honey } \\
\text { to treat fever and cough }\end{array}$ & Twice a day & Thrice a day & \\
\hline \multicolumn{10}{|l|}{ Arachnida } \\
\hline $\begin{array}{l}\text { Orthochirus } \\
\text { pallidus Pocock, } \\
\text { 1897/Scorpion/ } \\
\text { Bichoo, Larham }\end{array}$ & $\begin{array}{l}\text { Bannu, } \\
\text { Lakki, D.I. } \\
\text { Khan }\end{array}$ & $\begin{array}{l}\text { Whole } \\
\text { animal }\end{array}$ & $\begin{array}{l}\text { Brassica rapa L./ } \\
\text { Sarsoon/KUH-428a/ } \\
\text { Brassicaceae }\end{array}$ & Seeds & NA & $\begin{array}{l}\text { Scorpion is fried in } \\
\text { Brassica seeds oil and } \\
\text { used topically to reduce } \\
\text { pain and swelling of a } \\
\text { venomous bite }\end{array}$ & Twice a day & Twice a day & 4 \\
\hline
\end{tabular}

NA; data not available.

of considerable level due to poor socioeconomic conditions, lack of access to education, and most had opted to farm as their profession because of their elders. Mostly, respondents (16.21\%) were farmers having broad knowledge of ethnomedicine.

Thirty-two animal species were reported to be used by the local communities for curing 37 types of diseases including epilepsy, cancer, hepatitis, night blindness, whooping cough, asthma, paralysis, and brain hemorrhage among others. Use of Camelus dromedarius for treating cancer, hepatitis, diabetes, Capra hircus for enhancing sexual power and asthma, Oryctolagus cuniculus for paralysis, and Ovis aries for cough, flu, skin burn, weakness and joint pain has been reported earlier and were overlapping the current findings (Altaf et al., 2018). In Bahawalpur-Pakistan, the products/parts of the above-mentioned mammals have also been mentioned for skin diseases, jaundice, rickets, tuberculosis, weakness, paralysis, and asthma (Ahmad et al., 2021).

Similarly, 44 animal species, including Herpestes edwardsii, Sciurus caroliniensis, Bos indicus, Bubalus bubalis, and Vulpes bengalensis etc., were reported in Assam India to treat 40 diseases. The commonly treated diseases were cancer, asthma, rabies, epilepsy, piles, paralysis (Borah and Prasad, 2017). Local people of Ethiopia and Mauritius used 51 and 32 animal species to treat over 36 and 38 kinds of ailments, respectively (Kendie et al., 2018). Apart from Asia and Africa, animal use in ethnomedicine has also been documented in European countries (Quave et al.,
2010; Benitez, 2011). Different active agents that are being used as potential drugs have been isolated from various animals Daly et al. (2005), Cragg and Newman (2013), Rodrguez et al. (2017), Zhan et al. (2020) which show the medicinal importance of the animals. For instance, Bufo gargarizan, a traditionally used medicinal animal, is a rich source of bioactive agents and approximately 118 bufadienolide monomers and 11 indole alkaloids have been isolated from it to date. The extracts and isolated compounds exhibit a wide range of in vitro and in vivo pharmacological effects such as detoxification, reduce swelling, anti-inflammation, antitumor, and immunomodulation (Zhan et al., 2020).

In our findings, mammals remained as the highly utilized animal group for therapeutic purposes. Similar studies have been reported in Pakistan, North-Western Ethiopia, Nepal, and South Africa Whiting et al. (2013), Altaf et al. (2018), Adhikari et al. (2020) where mammals were mostly used as medicines. Most of these animals were domesticated and therefore, easily accessible. The local inhabitants also believed that mammals are the rich sources of proteins, supplementary foods, and medicines and are commonly practiced by the local communities for meat and milk. In contrast, extensive use of insects has also been documented in India (Chakravorty et al., 2011; Borah and Prasad, 2017). However, in some reports reptiles are among the highest animals used in ethnomedicines (Altaf et al., 2020; da 


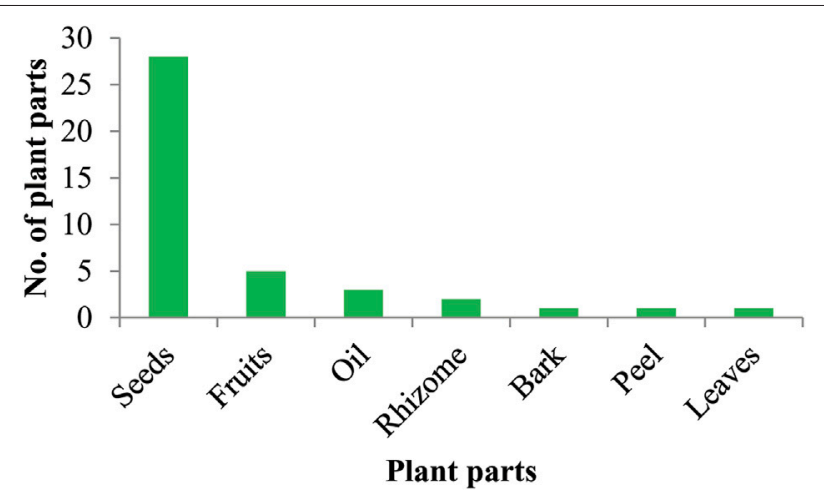

FIGURE 5 | Plant parts used in the preparation of ethnomedicine.

TABLE 4 | Informant consensus factor for animal and animal-plant recipes.
Disease categories

General body weakness

Pyrexia

Arthritis

Dermatological

Respiratory

Gastrointestinal

Nervous

Wounds

Anemia
Reproductive
16

$\begin{array}{ccc}\text { Nur } & \text { Nt } & \text { FIC } \\ 34 & 5 & 0.88 \\ 22 & 4 & 0.86 \\ 31 & 6 & 0.83 \\ 53 & 11 & 0.80 \\ 39 & 9 & 0.79 \\ 28 & 8 & 0.74 \\ 25 & 8 & 0.71 \\ 18 & 9 & 0.52 \\ 11 & 4 & 0.7 \\ 16 & 7 & 0.6\end{array}$

Nóbrega Alves et al., 2008; Fernandes-Ferreira et al., 2013). The number of different animal species shows the diversity in an area however, the composition of fauna, accessibility, and availability directly influences the zootherapeutic resources used in any given region (Alves and Rosa, 2007). Different indigenous tribal groups also sacrifice animals for different rituals and religious purposes in keeping with their mythological myths and beliefs. For example, people wear tiger and bear claws around their necks to protect from evils while animals like goats, buffalo, pigeons were sacrificed to please Gods for healing purposes (Solanki and Chutia, 2004; Mahawar and Jaroli, 2006; Alves, 2009).

Meat, whole animal, and milk were among the widely used animal products. Meat as the highest used part of ethnomedicine in Lahore and Jhelum has already been reported (Altaf et al., 2018). Similarly, another study in Ethiopia documented meat and fat as the commonly utilized medicinal products of animals (Kendie et al., 2018). In contrast, in some reports, the highest use of whole animals for medicinal purposes has also been documented (Borah and Prasad, 2017). Capra hircus, Macaca mulatta, Paraechinus micropus, Oryctolagus cuniculus, Funambulus palmarum, Anas platyrhynchos, and Gallus gallus meat was used to treat hepatitis, cough, cancer, asthma, epilepsy, anemia, weakness, and kidney problems. Similar uses of different animals' meat have been reported to treat patients suffering from paralysis, asthma, rheumatism, arthritis, poor vision, and

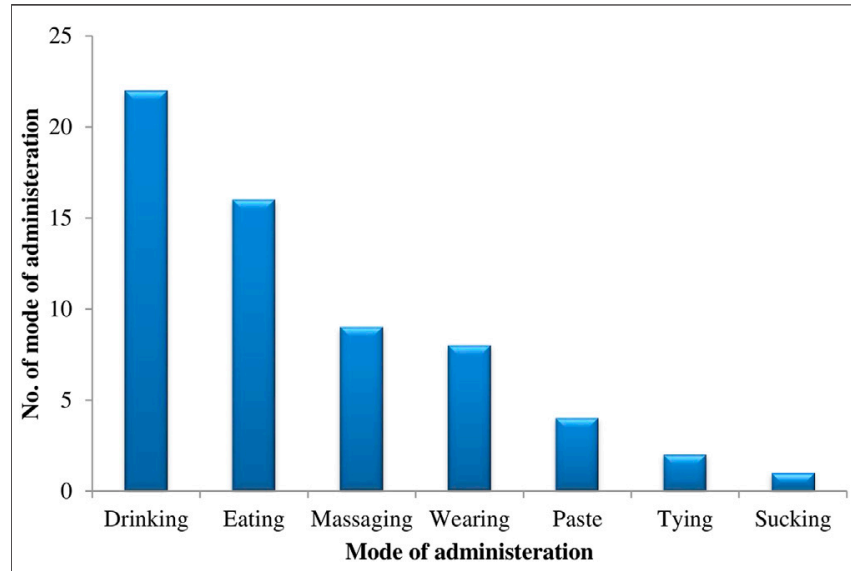

FIGURE 6 | Modes of administration of ethnomedicine.

TABLE 5 | Fidelity level of highly utilized animal species in traditional therapies.

\begin{tabular}{llccc} 
Animal species & Disease category & Ip & lu & FL \% \\
\hline Columba livia & Nervous & 16 & 20 & 80.0 \\
Oryctolagus cuniculus & Respiratory & 6 & 9 & 66.6 \\
Apis cerana & Dermatological & 17 & 37 & 46.0 \\
Labeo rohita & Dermatological & 3 & 11 & 27.3 \\
Gallus gallus & Pyrexia & 8 & 36 & 22.2 \\
Bos taurus & Gastrointestinal & 13 & 69 & 19.0 \\
Capra hircus & Arthritis & 3 & 23 & 13.0
\end{tabular}

tuberculosis (Adhikari et al., 2020). Columba livia meat was utilized for early onset of puberty in females in our study. However, patients with paralysis were given cooked meat of $C$. livia in Nepal Adhikari et al. (2020), while fresh blood was used in India for curing the same disease (Mahawar and Jaroli, 2007). Meat and meat products are significant sources of proteins, vitamins (vitamin B12), minerals (zinc, iron, and phosphorus), and provide other essential components to our diet (Biesalski, 2005; Williams, 2007; McAfee et al., 2010). Vitamin B12 (also known as cyanocobalamin) has been found to inhibit the HCV internal ribosome entry site (IRES)-dependent translation of a receptor gene in vitro (Lott et al., 2001). Similarly, iron deficiency can lead to severe anemia and is essential for heme and hemoglobin formation (Camaschella et al., 2016). These health improving effects and rich nutritious value could justify the use of meat of different animal species for treating different types of diseases.

The eggs of pigeon and chicken were utilized to treat blood pressure, fever, cough, joints pain, and chest infection. Eggs have been previously reported for treating similar diseases (Altaf et al., 2018). Eggs of G. gallus are being used for curing weakness and cough Ahmad et al. (2021), nasal congestion to stop bleeding and dysentery Shams et al. (2019), and reinforces potency and enhances libido (Lev, 2003). Eggshell has been found useful in the treatment of urinary stones (Ahmad et al., 2021). Similarly, the egg shell of Struthio camelus has been utilized for treating eye diseases (Lev, 2003). Research shows that eggs have high nutritional 
value and provide an excellent source of both water-soluble (B1 and B12) and lipid-soluble (A, D, E, and K) vitamins, omega-3fatty acids, and minerals such as phosphorus and iron (Anton et al., 2006). Moreover, lysozymes from egg albumin have antibacterial, antiviral activities (viral bronchitis, herpetic lesions, stomatitis, etc.), while ova albumin extracted from eggs is effective in preventing hypertension (Dedonder and Morias, 1974; Fujita et al., 1995).

Fats and oil of animals were used to treat baldness, joint, and muscle aches, and for sexual enhancement. It has been proven that fats and oil of animal origin contain omega-3 fatty acids which reduce inflammation (Wilson, 2015). Some studies have also verified that fats/oil of animals is beneficial in neurological disorders, atherosclerosis, thrombotic, and aging effects (Haag, 2003). However, rich fats comprised of a high fraction of saturated fatty acids are considered to be major factors of obesity, body mass gain, and heart disease (Anton et al., 2006). Therefore, the use of animal fat/oil could have adverse effects and may cause potential health issues.

Milk was utilized to relieve joints and back pain, gastric pain, treat cancer, paralysis, whooping cough, and reduce obesity. The findings are in parity with a study conducted by (Altaf et al., 2018). Milk contains nutritious and effective components that reduce joint pain, strengthen the body, and increase sexual potency (Alabdulkarim, 2012; Sabahelkhier et al., 2012). Milk is not only the source of bioactive components, but may also serve as an important delivery medium (Ebringer et al., 2008).

Apart from using animal products, people were also using animal-plant recipes. Plants and plant-derived products are usually used in combination with animal parts and byproducts to enhance the therapeutic effects of ethnomedicines (Borah and Prasad, 2017). Among the reported plant families, the most commonly used were Piperaceae and Apiaceae. Traditionally, individual plants of these families have also been used as folk medicine. In the present study, most of the plants of Piperaceae and Apiaceae were used as spices in recipe formulation as additional ingredients for good taste. Another main reason behind the wide use of these families in folk medicine is having vast pharmacological activities. Different compounds and extracts isolated from plant species belonging to Piperaceae have been experimentally tested for analgesic, antibacterial, antimalarial, and other pharmacological activities (Roersch, 2010). Similarly, plant species of Apiaceae possess antioxidant, anti-diuretic and anti-inflammatory activities (Dehpour et al., 2009; Matasyoh et al., 2009; Miguel et al., 2010; Hajhashemi et al., 2011). Cow milk was mixed with rhizome powder of $C$. longa to reduce injury pain and with honey to treat cough and throat infections. These preventive effects may be due to the presence of several nutrients and bioactive components in milk, among them caseins and whey proteins are of particular importance and have significant roles in immune and digestive systems, reduce blood pressure, antimicrobial, and anticarcinogenic effects (Ebringer et al., 2008). Compounds like curcumin (from C. longa) possess anti-inflammatory, antioxidant properties, and having a protective effect for rheumatism, sinusitis, biliary disorders, anorexia and immune diseases (Araujo and Leon, 2001; Yang et al., 2019). Literature has reported, the anti-arthritic effects of curcumin in humans with osteoarthritis (OA) and rheumatoid arthritis (RA) (Hewlings and Kalman, 2017). In the southern regions of Khyber Pakhtunkhwa, C. longa has also been used for pain and healing purposes (Adnan et al., 2014b). Similarly, the juice (leaves and barks) of Alstonia scholaris in combination with milk was used to treat chronic dysentery Borah and Prasad (2017) while cow urine is mixed with crushed seed of Sesbania grandiflora (L.) Pers (Bokful) for the treatment of epilepsy (Borah and Prasad, 2017). Some medicinal preparation where both plant and animals are utilized in combination is also reported from Brazil (Alves et al., 2013; Costa-Neto, 1999; da Nóbrega; Alves and Filho, 2007). However, the role of each component present in most of the mixtures is unclear. In animal-plant recipes, one component may act as a carrier, to enhance the therapeutic activity of each other, or reduce/mask the adverse effect(s) of one another. Hence, the role (s) of different components in mixture recipes should be explored in future research. These traditional ways of different combinations showing antagonistic/synergistic effects and providing new insights in the field of pharmacology that must be checked through in vitro and in vivo screening.

Cooking, boiling, juice, powder, frying, paste, and smoke were the common modes of ethnomedicine preparation. While drinking, eating, massaging, and wearing were the highly practiced modes of administration. Mostly, animal-based parts and products such as meat are properly cooked before consumption because raw consumption of animals' parts is haram (forbidden) in the Islamic religion. A similar trend was observed in Nepal where 12 types of preparations were used and cooked meat and other animal parts were commonly practiced (31\%) (Adhikari et al., 2020). On the other hand, raw consumption of animals and animal's parts was the highly used way of taking animals in India and Korea (Kim and Song, 2013; Vijayakumar et al., 2015; Borah and Prasad, 2017). However, the consumption of raw meat may increase the risks of transmitting different types of parasites and diseases to humans (Lohani, 2012; Kim and Song, 2013). Zoonotic diseases can be transmitted by direct contact with animals and also by using animal products as foods and medicines. For instance, raw consumption of milk has been associated with toxoplasmosis infection in the past and such practice is discouraged (Sacks et al., 1982). Therefore, proper preparation methods should be adopted for consuming animals and animals products as ethnomedicines.

Liquid and solids were frequently administered orally, while some were applied topically. These results were following the study conducted by Borah and Prasad (2017) showed that traditional medicines are mostly administered orally as compared to applied topically. However, the dermal application of ethnomedicines is still very reliable in joints pain, muscle aches, wounds, piles and bone fractures (Jaroli et al., 2010; Kim and Song, 2013). Additive substances like water, honey, oil, milk, sugar, salt, and colors were also used in ethnomedicine preparations same as in a previous study by (Kendie et al., 2018). These additives are useful for easy ingestion, increase solubility, decrease/minimize any bitter taste of ethnomedicine. 
Comparative analysis showed a limited number of ethnozoological studies conducted across the world. Medicinal use of animals is not extensively reported. India contributed predominantly to the ethnozoological studies and reported a higher number of studies as compared to other countries. Five studies were found to be published in Pakistan from Punjab regions describing the medicinal value of fauna and only one study was reported from Sawabi district of Khyber Pakhtunkhwa. Moreover, few studies were reported in the world where a mixture of plant and animal products was used for medicinal purposes. In this regard, the present data has potential value to the field of ethnobiology. Moreover, most studies were providing insufficient data regarding the traditional use of an animal as medicine. A detailed formulation of traditional medicine should be ensured in the future consisting of 1) accurate name of the reported species (scientific, vernacular, and English) 2) part and product used 3) mode of preparation 4) mode of administration 5) proper dose and number of doses per day 6) duration of treatment and 7) toxicity or adverse side effects (if any).

The quantitative analysis is of great importance in ethnomedicinal studies, because it provides baseline information for further ethnopharmacological studies. Animal species, both in animal-based and animal-plant recipes, having high FIC, and FL revealed the ethnomedicinal importance of these species and are recommended for further ethnopharmacological validation to better understand their zootherapeutic potential and explore the unknown bioactive compounds owing to ethnomedicinal efficacy.

\section{CONCLUSION}

Our findings suggest that local communities in the southern regions of Khyber Pakhtunkhwa have substantial knowledge about the formulation of ethnomedicine from both fauna and flora. This is the first attempt to document animal-based and animal-plant recipes from southern regions of Khyber Pakhtunkhwa, Pakistan. This study conserves the ethnobiological data and provides bases for pharmacological, phytochemical and synergistic studies. People either use an animal product/part directly or in combination with a plant part for curing different types of human ailments. The findings also suggest that ethnomedicine has a key role in the primary health care system of the study area by using a mixture of both fauna and flora. The animal-plant recipes provide new insights into drug development that could lead to the discovery of novel and effective drugs through synergistic mechanisms. Researchers are especially invited to conduct more research in this field to preserve and document traditional knowledge because this is eroding rapidly

\section{REFERENCES}

Adhikari, J. N., Bhattarai, B. P., Rokaya, M. B., and Thapa, T. B. (2020). Ethnomedicinal Uses of Vertebrates in the Chitwan-Annapurna Landscape, central Nepal. PLoS One 15 (10), e0240555. doi:10.1371/journal.pone.0240555

Adnan, M., Bibi, R., Mussarat, S., Tariq, A., and Shinwari, Z. K. (2014a). Ethnomedicinal and Phytochemical Review of Pakistani Medicinal Plants due to the death of elder traditional healers/herbalists and the modernization of the upcoming generation. Furthermore, animal products/parts with the highest FL, and FIC should further be studied in the future to assess the pharmacologically active compounds by using in vitro/in vivo assays.

\section{DATA AVAILABILITY STATEMENT}

The original contributions presented in the study are included in the article/Supplementary Material, further inquiries can be directed to the corresponding authors.

\section{ETHICS STATEMENT}

The animal study was reviewed and approved by Ethical Research Committee of Kohat University of Science and Technology, Kohat (KUST) Ref. No. KUST/Ethical Committee/17-12.

\section{AUTHOR CONTRIBUTIONS}

SM and MA designed the research study. MA, RU, and RAM supervised the study. SM, RA, and SA conducted the field survey and collected the ethnomedicinal data from the local people. SM, RA, and SA analyzed the data and drafted the manuscript. MA, $\mathrm{RU}$, and RAM helped during text incorporation and provided critical comments for improvement of the manuscript. Finally, all the authors have read and approved the final manuscript.

\section{FUNDING}

This research was funded by the Research Support supporting Project at King Saud University via Research Support Project Number (RSP/2021/119).

\section{ACKNOWLEDGMENTS}

This study is part of SM's Doctor of Philosophy (Ph.D.) dissertation. Participants of the survey are highly acknowledged for sharing their information. Authors are also thankful to Kohat University of Science and Technology, KUST ORIC project entitled "Diversity and Biological Efficacy of Ethnobotanically Used Pollyherbal Mixtures against Gastrointestinal Infections in Khyber Pakhtunkhwa.”

Used as Antibacterial Agents against Escherichia coli. Ann. Clin. Microbiol. Antimicrob. 13, 40. doi:10.1186/s12941-014-0040-6

Adnan, M., Ullah, I., Tariq, A., Murad, W., Azizullah, A., Khan, A. L., et al. (2014b). Ethnomedicine Use in the War Affected Region of Northwest Pakistan. J. Ethnobiol. Ethnomed. 10 (1), 16. doi:10.1186/ 1746-4269-10-16

Adnan, M., Tariq, A., Bibi, R., Mussarat, S., Fatima, B., Ali, N., et al. (2018). Traditional Medicines and Their In-Vitro Proof against Staphylococcus aureus 
in Pakistan. Asian Pac. J. Trop. Med. 11 (6), 355-368. doi:10.4103/19957645.234763

Ahmad, S., Akram, M., Riaz, M., Munir, N., Mahmood Tahir, I., Anwar, H., et al. (2021). Zootherapy as Traditional Therapeutic Strategy in the Cholistan Desert of Bahawalpur-Pakistan. Vet. Med. Sci. doi:10.1002/vms3.491

Alabdulkarim, B. (2012). Effect of Camel Milk on Blood Glucose, Cholesterol, Triglyceride and Liver Enzymes Activities in Female Albino Rats. World Appl. Sci. J. 17 (11), 1394-1397.

Ali, S. (1998). Zoogeography Palaeontology and Wildlife Management. Hyderabad: Nasseem Book Publisher.

Ali, W., Javid, A., Hussain, A., and Bukhari, S. M. (2017). Public Attitude towards Amphibian and Reptiles in District Kasur, Punjab, Pakistan. J. Zool. 32 (2), $173-178$.

Altaf, M., Abbasi, A. M., Umair, M., Amjad, M. S., Irshad, K., and Khan, A. M. (2020). The Use of Fish and Herptiles in Traditional Folk Therapies in Three Districts of Chenab Riverine Area in Punjab, Pakistan. J. Ethnobiol. Ethnomed. 16 (1), 38. doi:10.1186/s13002-020-00379-z

Altaf, M., Javid, A., Umair, M., Iqbal, K. J., Rasheed, Z., and Abbasi, A. M. (2017). Ethnomedicinal and Cultural Practices of Mammals and Birds in the Vicinity of River Chenab, Punjab-Pakistan. J. Ethnobiol. Ethnomed. 13 (1), 41. doi:10.1186/ s13002-017-0168-5

Altaf, M., Umair, M., Abbasi, A. R., Muhammad, N., and Abbasi, A. M. (2018). Ethnomedicinal Applications of Animal Species by the Local Communities of Punjab, Pakistan. J. Ethnobiol. Ethnomed. 14 (1), 55. doi:10.1186/s13002-018-0253-4

Alves, R. R. (2009). Fauna Used in Popular Medicine in Northeast Brazil. J. Ethnobiol. Ethnomed. 5, 1. doi:10.1186/1746-4269-5-1

Alves, R. R., and Rosa, I. L. (2005). Why Study the Use of Animal Products in Traditional Medicines? J. Ethnobiol. Ethnomed. 1 (1), 5. doi:10.1186/17464269-1-5

Alves, R. R., and Rosa, I. L. (2007). Zootherapeutic Practices Among Fishing Communities in North and Northeast Brazil: A Comparison. J. Ethnopharmacol. 111 (1), 82-103. doi:10.1016/j.jep.2006.10.033

Alves, R. R. d. N., and Filho, G. A. P. (2007). Commercialization and Use of Snakes in North and Northeastern Brazil: Implications for Conservation and Management. Biodivers. Conserv. 16 (4), 969-985. doi:10.1007/s10531-006-9036-7

Alves, R. R. N., Santana, G. G., and Rosa, I. L. (2013). "The Role of AnimalDerived Remedies as Complementary Medicine in Brazil," in Animals in Traditional Folk Medicine (Springer), 289-301. doi:10.1007/978-3-64229026-8_13

Anton, M., Nau, F., and Nys, Y. (2006). Bioactive Egg Components and Their Potential Uses. Worlds Poult. Sci. J. 62 (3), 429-438. doi:10.1079/ wps2005105

Araújo, C. C., and Leon, L. L. (2001). Biological Activities of Curcuma Longa L. Mem. Inst. Oswaldo Cruz 96 (5), 723-728. doi:10.1590/s0074-02762001000500026

Arshad, M., Ahmad, M., Ahmed, E., Saboor, A., Abbas, A., and Sadiq, S. (2014). An Ethnobiological Study in Kala Chitta hills of Pothwar Region, Pakistan: Multinomial Logit Specification. J. Ethnobiol. Ethnomed. 10 (1), 13. doi:10.1186/1746-4269-10-13

Benítez, G. (2011). Animals Used for Medicinal and Magico-Religious Purposes in Western Granada Province, Andalusia (Spain). J. Ethnopharmacol. 137 (3), 1113-1123. doi:10.1016/j.jep.2011.07.036

Biesalski, H. K. (2005). Meat as a Component of a Healthy Diet - Are There Any Risks or Benefits if Meat Is Avoided in the Diet? Meat Sci. 70 (3), 509-524. doi:10.1016/j.meatsci.2004.07.017

Borah, M. P., and Prasad, S. B. (2017). Ethnozoological Study of Animals Based Medicine Used by Traditional Healers and Indigenous Inhabitants in the Adjoining Areas of Gibbon Wildlife Sanctuary, Assam, India. J. Ethnobiol. Ethnomed. 13 (1), 39. doi:10.1186/s13002-017-0167-6

Camaschella, C., Pagani, A., Nai, A., and Silvestri, L. (2016). The Mutual Control of Iron and Erythropoiesis. Int. J. Lab. Hematol. 38, 20-26. doi:10.1111/ ijlh. 12505

Chakravorty, J., Meyer-Rochow, V. B., and Ghosh, S. (2011). Vertebrates Used for Medicinal Purposes by Members of the Nyishi and Galo Tribes in Arunachal Pradesh (North-East India). J. Ethnobiol. Ethnomed. 7 (1), 13. doi:10.1186/ 1746-4269-7-13

Costa-Neto, E. M. (1999). Healing with animals in Feira de Santana city, Bahia, Brazil. J. Ethnopharmacol. 65 (3), 225-230. doi:10.1016/s0378-8741(98)00158-5
Cragg, G. M., and Newman, D. J. (2013). Natural Products: a Continuing Source of Novel Drug Leads. Biochim. Biophys. Acta 1830 (6), 3670-3695. doi:10.1016/ j.bbagen.2013.02.008

da Nóbrega Alves, R. R., da Silva Vieira, W. L., and Santana, G. G. (2008). Reptiles Used in Traditional Folk Medicine: Conservation Implications. Biodivers. Conserv. 17 (8), 2037-2049. doi:10.1007/s10531-007-9305-0

Daly, J. W., Spande, T. F., and Garraffo, H. M. (2005). Alkaloids from Amphibian Skin: a Tabulation of over Eight-Hundred Compounds. J. Nat. Prod. 68 (10), 1556-1575. doi:10.1021/np0580560

Day, F. (1889). Fauna of British India, Including Ceylon and Burma. Fishes 1, $1-548$.

Dedonder, C., and Morias, J. (1974). Topical Treatment of Viral and Non-viral Cutaneous Lesions with Lysozyme Ointment. Medikon 3 (5), 21-22.

Dehpour, A. A., Ebrahimzadeh, M. A., Fazel, N. S., and Mohammad, N. S. (2009). Antioxidant Activity of the Methanol Extract of Ferula Assafoetida and its Essential Oil Composition. Grasas y aceites 60 (4), 405-412.

Ebringer, L., Ferencík, M., and Krajcovic, J. (2008). Beneficial Health Effects of Milk and Fermented Dairy Products-Rreview. Folia Microbiol. (Praha) 53 (5), 378-394. doi:10.1007/s12223-008-0059-1

Fernandes-Ferreira, H., Mendonca, S. V., Cruz, R. L., Borges-Nojosa, D. M., and Nobrega Alves, R. R. (2013). Hunting of Herpetofauna in Montane, Coastal, and Dryland Areas of Northeastern Brazil. Herpetol. Conserv. Biol. 8 (3), 652-666.

Fujita, H., Sasaki, R., and Yoshikawa, M. (1995). Potentiation of the Antihypertensive Activity of Orally Administered Ovokinin, a Vasorelaxing Peptide Derived from Ovalbumin, by Emulsification in Egg Phosphatidylcholine. Biosci. Biotechnol. Biochem. 59 (12), 2344-2345. doi:10.1271/bbb.59.2344

Haag, M. (2003). Essential Fatty Acids and the Brain. Can. J. Psychiatry 48 (3), 195-203. doi:10.1177/070674370304800308

Hajhashemi, V., Sajjadi, S. E., and Zomorodkia, M. (2011). Antinociceptive and Anti-inflammatory Activities of Bunium Persicum Essential Oil, Hydroalcoholic and Polyphenolic Extracts in Animal Models. Pharm. Biol. 49 (2), 146-151. doi:10.3109/13880209.2010.504966

Hewlings, S. J., and Kalman, D. S. (2017). Curcumin: A Review of its Effects on Human Health. Foods 6 (10), 92. doi:10.3390/foods6100092

Hoffman, B., and Gallaher, T. (2007). Importance Indices in Ethnobotany. Ethnobot. Res. App. 5, 201-218. doi:10.17348/era.5.0.201-218

Ibrar, M., Hussain, F., and Sultan, A. (2007). Ethnobotanical Studies on Plant Resources of Ranyal hills, District Shangla, Pakistan. Pak. J. Bot. 39 (2), 329.

Jaroli, D. P., Mahawar, M. M., and Vyas, N. (2010). An Ethnozoological Study in the Adjoining Areas of Mount Abu Wildlife Sanctuary, India. J. Ethnobiol. Ethnomed. 6 (1), 6. doi:10.1186/1746-4269-6-6

Kendie, F. A., Mekuriaw, S. A., and Dagnew, M. A. (2018). Ethnozoological Study of Traditional Medicinal Appreciation of Animals and Their Products Among the Indigenous People of Metema Woreda, North-Western Ethiopia. J. Ethnobiol. Ethnomed. 14 (1), 37. doi:10.1186/s13002-018-0234-7

Khan, M. S. (2006). Amphibians and Reptiles of Pakistan. Malabar, Florida, USA: Krieger Publishing Company.

Khan, M. S. (2004). Annotated Checklist of Amphibians and Reptiles of Pakistan. Asiat. Herpetol. Res. 10, 191-201.

Kim, H., and Song, M. J. (2013). Ethnozoological Study of Medicinal Animals on Jeju Island, Korea. J. Ethnopharmacol. 146 (1), 75-82. doi:10.1016/j.jep.2012.11.011

Lev, E. (2003). Traditional Healing with Animals (Zootherapy): Medieval to Present-Day Levantine Practice. J. Ethnopharmacol. 85 (1), 107-118. doi:10.1016/s0378-8741(02)00377-x

Lohani, U., Rajbhandari, K., and Shakuntala, K. (2008). Need for Systematic Ethnozoological Studies in the Conservation of Ancient Knowledge Systems of Nepal-a Review. India J. Trad. Know. 7 (4), 634-637.

Lohani, U. (2012). Zootherapeutic Knowledge of Two Ethnic Populations from Central Nepal. Stud. Ethno-Medicine 6 (1), 45-53. doi:10.1080/ 09735070.2012.11886420

Lott, W. B., Takyar, S. S., Tuppen, J., Crawford, D. H., Harrison, M., Sloots, T. P., et al. (2001). Vitamin B12 and Hepatitis C: Molecular Biology and Human Pathology. Proc. Natl. Acad. Sci. U S A. 98 (9), 4916-4921. doi:10.1073/pnas.081072798

Mahawar, M. M., and Jaroli, D. P. (2006). Animals and Their Products Utilized as Medicines by the Inhabitants Surrounding the Ranthambhore National Park, India. J. Ethnobiol. Ethnomed. 2, 46. doi:10.1186/1746-4269-2-46 
Mahawar, M. M., and Jaroli, D. P. (2007). Traditional Knowledge on Zootherapeutic Uses by the Saharia Tribe of Rajasthan, India. J. Ethnobiol. Ethnomed. 3, 25. doi:10.1186/1746-4269-3-25

Mahomoodally, F., Samoisy, A. K., and Suroowan, S. (2019). Ethnozoological Practices in Rodrigues Island of the Mascarene Archipelago. J. Ethnopharmacol. 245, 112163. doi:10.1016/j.jep.2019.112163

Malik, K., Ahmad, M., Bussmann, R. W., Tariq, A., Ullah, R., Alqahtani, A. S., et al. (2018). Ethnobotany of Anti-hypertensive Plants Used in Northern Pakistan. Front. Pharmacol. 9, 789. doi:10.3389/fphar.2018.00789

Mallon, D. (1991). Biodiversity Guide to Pakistan. Cambridge, UK: World Conservation Monitoring Centre.

Matasyoh, J. C., Maiyo, Z. C., Ngure, R. M., and Chepkorir, R. (2009). Chemical Composition and Antimicrobial Activity of the Essential Oil of Coriandrum Sativum. Food Chem. 113 (2), 526-529. doi:10.1016/ j.foodchem.2008.07.097

McAfee, A. J., McSorley, E. M., Cuskelly, G. J., Moss, B. W., Wallace, J. M., Bonham, M. P., et al. (2010). Red Meat Consumption: An Overview of the Risks and Benefits. Meat Sci. 84 (1), 1-13. doi:10.1016/j.meatsci.2009.08.029

Miguel, M. G., Cruz, C., Faleiro, L., Simões, M. T., Figueiredo, A. C., Barroso, J. G., et al. (2010). Foeniculum Vulgare Essential Oils: Chemical Composition, Antioxidant and Antimicrobial Activities. Nat. Prod. Commun. 5 (2), 319-328. doi:10.1177/1934578x1000500231

Mirza, M. R. (1975). Freshwater Fishes and Zoogeography of Pakistan. Btd 45 (2), 143-180. doi:10.1163/26660644-04502001

Mirza, Z., and Wasiq, H. (2007). A Field Guide to Birds of Pakistan Bookland. Lahore.

Mussarat, S., AbdEl-Salam, N. M., Tariq, A., Wazir, S. M., Ullah, R., and Adnan, M. (2014). Use of Ethnomedicinal Plants by the People Living Around Indus River. Evid. Based Complement. Alternat. Med. 2014. doi:10.1155/2014/212634

Mussarat, S., Adnan, M., Begum, S., Alqarawi, A. A., Rehman, S. U., and Abd_Allah, E. F. (2021). Diversity of Traditionally Used Polyherbal Medicines. Pak. J. Bot. 53(4). doi:10.30848/pjb2021-4(15)

Oudhia, P. (1995). Traditional Knowledge about Medicinal Insects, Mites and Spiders in Chhattisgarh, India. Insect Environ. 4, 57-58.

Pocock, R. (1900). The Fauna of India, Including Ceylon and Burma (Arachnida). London: Taylor \& Francis.

Quave, C. L., Lohani, U., Verde, A., Fajardo, J., Rivera, D., Obón, C., et al. (2010). A Comparative Assessment of Zootherapeutic Remedies from Selected Areas in Albania, Italy, Spain and Nepal. J. Ethnobiol. 30 (1), 92-125. doi:10.2993/02780771-30.1.92

Roberts, T. (1991). The Birds of Pakistan, Vol. II. Karachi: Printed at Oxford University Press.

Roberts, T. J. (2005a). Field Guide to the Large and Medium-Sized Mammals of Pakistan. Oxford University Press.

Roberts, T. J. (2005b). Field Guide to the Small Mammals of Pakistan. Oxford Univeristy Press.

Roberts, T. (1997). The Mammals of pakistan. revised ed. Karachi, Pakistan: Oxford University Press, 525.

Rodríguez, C., Rollins-Smith, L., Ibáñez, R., Durant-Archibold, A. A., and Gutiérrez, M. (2017). Toxins and Pharmacologically Active Compounds from Species of the Family Bufonidae (Amphibia, Anura). J. Ethnopharmacol. 198, 235-254. doi:10.1016/j.jep.2016.12.021

Roersch, C. M. (2010). Piper Umbellatum L.: a Comparative Cross-Cultural Analysis of its Medicinal Uses and an Ethnopharmacological Evaluation. J. Ethnopharmacol. 131 (3), 522-537. doi:10.1016/j.jep.2010.07.045

Sabahelkhier, M., Faten, M., and Omer, F. (2012). Comparative Determination of Biochemical Constituents between Animals (Goat, Sheep, Cow and Camel) Milk with Human Milk. Res. J. Recent Sci. 2277, 2502.
Sacks, J. J., Roberto, R. R., and Brooks, N. F. (1982). Toxoplasmosis Infection Associated with Raw Goat's Milk. JAMA 248 (14), 1728-1732. doi:10.1001/ jama.1982.03330140038029

Sandhya, B., Thomas, S., Isabel, W., and Shenbagarathai, R. (2006). Ethnomedicinal Plants Used by the Valaiyan Community of Piranmalai hills (Reserved forest), Tamilnadu, India.-A Pilot Study. Afr. J. Tradit. Complement. Altern. Med. 3 (1), 101-114.

Shaheen, S., Abbas, S., Hussain, J., Mabood, F., Umair, M., Ali, M., et al. (2017). Knowledge of Medicinal Plants for Children Diseases in the Environs of District Bannu, Khyber Pakhtoonkhwa (KPK). Front. Pharmacol. 8, 430. doi:10.3389/ fphar.2017.00430

Shams, W. A., Rehman, G., Ullah, Z., Ara, S., Niaz, S., Ali, A., et al. (2019). Zootheraputic Practices in Swabi District of Khyber Pakhtunkhawa Pakistan. Pure Appl. Biol. (Pab) 8 (1), 222-231.

Solanki, G. S., and Chutia, P. (2004). Ethno Zoological and Socio-Cultural Aspects of Monpas of Arunachal Pradesh. J. Hum. Ecol. 15 (4), 251-254. doi:10.1080/ 09709274.2004.11905701

Tripathy, B. (1995). Drabya Guna Kalpa Druma, Orissa (Vols. I \& II). Publ. DP Tripathy, Bellaguntha. (Ganjam District) 5.

Umair, M., Altaf, M., Bussmann, R. W., and Abbasi, A. M. (2019). Ethnomedicinal Uses of the Local flora in Chenab Riverine Area, Punjab Province Pakistan. J. Ethnobiol. Ethnomed. 15 (1), 7. doi:10.1186/s13002-019-0285-4

Vijayakumar, S., Yabesh, J. E., Prabhu, S., Ayyanar, M., and Damodaran, R. (2015). Ethnozoological Study of Animals Used by Traditional Healers in Silent Valley of Kerala, India. J. Ethnopharmacol. 162, 296-305. doi:10.1016/j.jep.2014.12.055

Whiting, M. J., Williams, V. L., and Hibbitts, T. J. (2013). Animals Traded for Traditional Medicine at the Faraday Market in South Africa: Species Diversity and Conservation Implications. Animals in Traditional Folk Medicine. Springer, 421-473. doi:10.1007/978-3-642-29026-8_19

Who (2019). World Health Organization Global Report on Traditional and Complementary Medicine.

Williams, P. (2007). Nutritional Composition of Red Meat. Nutr. Diet. 64, S113-S119. doi:10.1111/j.1747-0080.2007.00197.x

Wilson, L. (2015). Fats and Oils for Optimum Health. The Center for Development. Yang, M., Akbar, U., and Mohan, C. (2019). Curcumin in Autoimmune and Rheumatic Diseases. Nutrients 11 (5), 1004. doi:10.3390/nu11051004

Zhan, X., Wu, H., Wu, H., Wang, R., Luo, C., Gao, B., et al. (2020). Metabolites from Bufo gargarizans (Cantor, 1842): A Review of Traditional Uses, Pharmacological Activity, Toxicity and Quality Control. J. Ethnopharmacol. 246, 112178. doi:10.1016/j.jep.2019.112178

Conflict of Interest: The authors declare that the research was conducted in the absence of any commercial or financial relationships that could be construed as a potential conflict of interest.

Publisher's Note: All claims expressed in this article are solely those of the authors and do not necessarily represent those of their affiliated organizations, or those of the publisher, the editors and the reviewers. Any product that may be evaluated in this article, or claim that may be made by its manufacturer, is not guaranteed or endorsed by the publisher.

Copyright (C) 2021 Mussarat, Ali, Ali, Mothana, Ullah and Adnan. This is an openaccess article distributed under the terms of the Creative Commons Attribution License (CC BY). The use, distribution or reproduction in other forums is permitted, provided the original author(s) and the copyright owner(s) are credited and that the original publication in this journal is cited, in accordance with accepted academic practice. No use, distribution or reproduction is permitted which does not comply with these terms. 